\title{
INFORMING CONSENT: VOTER IGNORANCE, POLITICAL PARTIES, AND ELECTION LAW
}

\author{
Christopher S. Elmendorf* \\ David Schleicher**
}

This Article examines what law can do to enable an electorate comprised of mostly ignorant voters to obtain meaningful representation and to hold elected officials accountable for the government's performance. Drawing on a half-century of research by political scientists, we argue that political parties are both the key to good elections and a common cause of electoral dysfunction. Party labels can help rational, low-information voters by providing them with credible, low cost, and easily understood signals of candidates' ideology and policy preferences. But in federal systems, any number of forces may result in party cues that are poorly calibrated to the electorate and issue space of subnational governments. Further, the geographic clustering of partisan voters can lead to persistently dysfunctional elections at subnational levels, however well calibrated the majorparty cues, because in these communities the aggregation of votes will not neutralize (as it otherwise would) the ballots cast by citizens whose party ties reflect their upbringing and social milieu more than their observations about what the government has done. To date, these problems have largely been the province of political science and sociology. We argue that they are problems of, and for, election law. Statutes and court decisions govern who selects a party's candidates, what information appears on the ballot, and any number of other variables that affect the meaning and utility of party labels. Our analysis challenges the focus of decades of political science and legal scholar-

* Elmendorf is Professor of Law, University of California at Davis

** Schleicher is Associate Professor of Law, George Mason University School of Law, and Visiting Professor of Law, New York University School of Law.

For their enormously helpful feedback, we are indebted to Cheryl Boudreau, Bruce Cain, Guy Charles, Joey Fishkin, Heather Gerken, Ethan Leib, Justin Levitt, Rick Pildes, Mike Pitts, Jed Purdy, Ilya Somin, Nick Stephanopoulos, and Matt Stephenson, and to faculty workshop and seminar participants at Duke Law School, UC Hastings College of the Law, and Yale Law School. Thanks also to Mark Quist and Mary Watson for their work as research assistants. 
ship, and sheds new light on important questions about party regulation, ballot design, the choice between partisan and nonpartisan elections, and the constitutional law of party rights.

\section{TABLE OF CONTENTS}

INTRODUCTION

I. VOTING WITHOUT (MUCH) INFORMATION:

AN INTELLECTUAL HISTORY

A. "Constantly Bamboozled"? The American Voter As Political Ignoramus.

B. All in the Family: The American Voter and Party Identification

C. "A Reasonably Rational Fellow": The Running Tally, the Miracle of Aggregation, and Macropartisanship ..

D. "Partisan Hearts and Minds": Dissent from the Running Tally and Macropartisanship .................................... 379

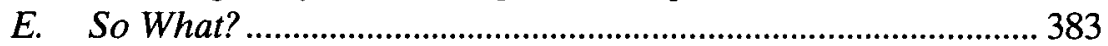

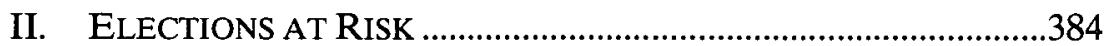

A. Elections Without Party Brands: Nonpartisan, Primary, and Direct Democracy Elections ............................................. 385

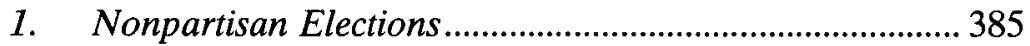

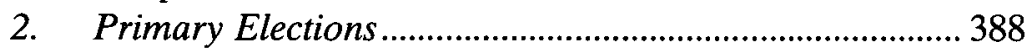

3. Direct Democracy Elections............................................... 390

B. Elections With Dysfunctional Party Brands: Mismatch and Michigan Problems in State and Local Elections............. 393

1. The Problems Defined ......................................................... 394

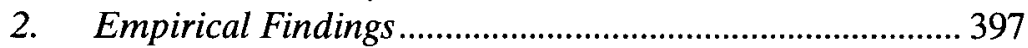

a. Evidence from Municipal Elections.................. 397

b. Evidence from State-Level Elections.............. 398

3. The Mechanics of "Party Breakdown" in Subnational Democracies.................................................... 403

a. Michigan Voter Imbalance ............................... 404

b. Mismatched Perceptions ................................... 404

c. Party-Brand Mismatch and Barriers to Rebranding................................................... 405

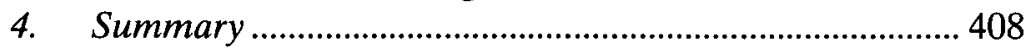

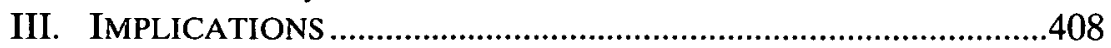

A. Better Voting: On Parties and Party Substitutes...................... 409

1. Better Partisan Voting (Through Law) ........................... 412

a. Availability ....................................................... 412

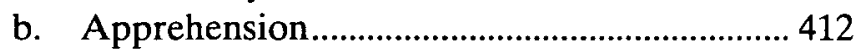

c. Consistency ........................................................ 414 


\section{d. Tailoring (Undoing Party-Brand} Mismatch)

2. Substitutes for the National Party Labels.

a. The Executive Cue

b. Advisory Primaries

B. The Constitutional Law of Party Rights .................................. 424

1. State Interests in the Regulation of Political Parties........ 424

2. How to Think About Burdens on Political

Party Association

IV. CONCLUSION: ELECTION LAW IN

LIGHT OF VOTER IGNORANCE

\section{INTRODUCTION}

Most voters are astonishingly ignorant of the basic facts about government and politics. Pioneering survey research by University of Michigan political scientists focused the discipline's attention on this problem half a century ago. ${ }^{1}$ In the years since, successive generations of political scientists have tried to understand whether-and if so, how-elections yield meaningfully democratic outcomes notwithstanding widespread voter ignorance.

The political science debate about how well elections work, given voter ignorance, has largely passed legal scholarship by. ${ }^{2}$ This Article

1. Angus Campbell et AL., The American Voter 15-17 (1960).

2. To the extent that election law scholars address questions of voter information and competence, they do so largely in writing about campaign finance. See infra notes 221-28 and accompanying text. There are, of course, some exceptions. See, e.g., Heather K. Gerken, The Democracy INDEX: WHY OUR ELECTION SYSTEM IS FAILING AND HOW TO FIX IT 5-16 (2009) (proposing ranking of states based on election performance, in part to provide underinformed voters with voting cue for Secretary of State races); Christopher S. Elmendorf, Representation Reinforcement Through Advisory Commissions: The Case of Election Law, 80 N.Y.U. L. REv. 1366, 1371-72 (2005) (arguing that advisory election commissions could improve election law policymaking by providing salient heuristics); Elizabeth Garrett, The Law and Economics of "Informed Voter" Ballot Notations, 85 VA. L. REV. $1533,1584-86$ (1999) (proposing use of candidate statements on ballot to improve voter performance); Heather K. Gerken \& Douglas B. Rand, Creating Better Heuristics for the Presidential Primary: The Citizen Assembly, 125 POL. SCl. Q. 233 (2010) (exploring early primaries and citizen commissions as heuristic guides for low-information voters in presidential primaries); Richard H. Pildes, Why the Center Does Not Hold: The Causes of Hyperpolarized Democracy in America, 99 CAL. L. REV. 273, 330 (2011) (noting that polarized political parties may improve voter competence); David Schleicher, What if Europe Held an Election and No One Cared?, 52 HARv. INT'L L.J. 109 (2011) [hereinafter Schleicher, What $I f]$ (explaining failures of European Parliament elections in terms of "mismatched" party system, election law, and rational voter ignorance); David Schleicher, Why Is There No Partisan Competition in City Council Elections?: The Role of Election Law, 23 J. L. \& POL. 419 (2007) [hereinafter Schleicher, Why] (arguing that city council elections are not competitive because of the interaction between voter ignorance, election laws, and "mismatched" parties); Ilya Somin, Political Ignorance and the Countermajoritarian Difficulty: A New Perspective on the Central Obsession of Constitutional Theory, 89 IOWA L. REV. 1287, 1310, 1313-14 (2004) (arguing that countermajoritarian difficulty is less difficult when voter ignorance is considered). 
provides the beginnings of a corrective. Our aim is to depict the essential contours of the voter-information problem and to explain how election law might change in response. We also hope to shift the focus of political science research on voting and elections. The dominant question in the field for the last fifty years has been, "Do elections work, given the voter information problem?" We think it more profitable to ask, "Which elections work least well, and what can law do to make them work better?"

We begin, in Part I, by recapping the political science of voter ignorance. Though there is no disciplinary consensus about whether elections "work," given what voters know, political science has revealed certain mechanisms through which a low-information electorate may behave as if reasonably well informed. To the extent that the electorate performs well, the credit is largely due to political parties, and to the statistical properties of aggregation (which can neutralize uninformed votes). At their best, political parties provide voters with simple, reliable, and easily learned cues about candidates' ideology and policy preferences. Meanwhile, the organization of legislatures along party lines enables voters to identify the dominant governing coalition and to connect their stray observations of politics and policy to the party then in charge. This process, aggregated across the electorate as a whole, can yield collectively rational responses to information about governmental undertakings. As the political scientist E.E. Schattschneider famously noted, "[M]odern democracy is unthinkable save in terms of the parties."

But the existence of political parties is not a panacea. Voters may fail to discern the partisan balance of power, or the issue positions of the parties. Voters may blame the governing coalition for events beyond its control, or judge its performance myopically. Moreover, not all voters see and respond to parties in informational terms. Many have an essentially affective rather than instrumental relationship to their party of choice. Partisanship for them is largely an incident of upbringing, one which resembles nothing so much as felt ties to family, religion, clan, or tribe. We shall refer to these citizens as "Michigan Voters," in recognition of foundational research on the sociology of partisanship by political scientists at the University of Michigan. ${ }^{5}$

Thus, although parties are necessary for the operation of mass democracy given voter inattention to politics, they do not "solve" the problem of voter ignorance tout court or even improve it to the same degree in all places and at all times. Rather, party cues work more or less well

3. See infra Part I.

4. E.E. SChatTSCHNEIder, PARTY Government 1 (1942).

5. For ease of exposition this paper generally treats citizens as ideal types-either pure "Michigan Voters" or pure "Bayesian updaters," i.e., voters who neutrally use new information to update their priors about the consequences of putting one party or the other into power. No doubt most people are mixed types; we all have a bit of Maize and Blue in our party identifications. The important question is the aggregate degree and distribution of affective partisanship in the electorate. 
depending on factors that vary predictably across different types of elections. This is our central point in Part II, which takes up the question of which elections are likely to suffer the most on account of voter ignorance, and why. (Throughout this Article, we will treat elections as performing well insofar as they yield the result that would have occurred if voters followed politics and policy closely and voted based on their policy preferences and expectations about government performance. ${ }^{6}$ )

National elections, which receive the bulk of political scientists' attention, present comparatively propitious conditions for collective competence. The national parties - Democrats and Republicans-have ideologically differentiated platforms that are reasonably stable over time. The parties also organize the legislature into clear voting blocs, enabling voters to see who's in charge. Party labels on the ballot make it easy for voters to link parties and candidates. And, critically, the major-party brands are substantively well-tailored to the national issue space and electorate. By this we mean (1) that learning a candidate's party affiliation enables voters to infer the candidate's position on most significant issues of national policy; (2) that the packaging of policy positions into party labels tracks latent preference correlations within the electorate (so that voters who favor the Democratic position on issue $x$ are also likely to favor the Democratic stance on issue $y$ ); and (3) that the major party brands divide the electorate fairly evenly, such that roughly half of the electorate prefers the Democratic brand to the Republican brand and vice versa.

One probable and salutary consequence of the balance between Democratic and Republican identifiers in the national electorate is neutralization of the Michigan Vote. That is, votes cast by affective Democrats are likely to cancel out those of affective Republicans, leaving control of Congress and the White House in the hands of voters whose partisan preferences respond to information.

By contrast, many state and local elections (as well as primary elections at all levels) present significant cause for concern. As Part II explains, this is not simply because voters pay less attention to these elections. It is also because our system of election law does not provide voters in these elections with on-ballot voting cues of comparable quality to the party labels used in national elections.

Party labels are absent from the ballot in initiative and referendum elections, most local government elections, and some elections for statelevel office. ' In other subnational elections, party labels are present but substantively "mismatched"-not well tailored-to the issue space and

6. Many political scientists make essentially the same move. See, e.g., Larry M. Bartels, Uninformed Votes: Information Effects in Presidential Elections, 40 AM. J. PoL. SCI. 194 (1996); Richard R. Lau \& David P. Redlawsk, Voting Correctly, 91 AM. POL. SCI. REV. 585 (1997).

7. See infra Part II.A.1. 
electorate for the government in question. ${ }^{8}$ Where subnational wings of the national parties do not compete for the local median voter on the basis of issues specific to the corresponding level of government, the party brands will not fulfill their proper informational role. (We will argue that failures of rebranding can occur for a variety of legal and strategic reasons.)

Subnational elections often suffer as well from mismatch at the level of perceptions: many voters do not see and respond to the local policy content of the major-party brands. Oblivious or confused, these voters base their decisions in subnational elections on what they know about the parties' position-taking and performance at the national level. A further problem is that in subnational polities that are overwhelmingly Democratic or Republican by national party ID, the Michigan Vote is not likely to be self-canceling. ${ }^{9}$ It will, instead, foreordain the general election winners, relegating the choice of lawmakers and control of government to unlabeled, information-poor primary elections in which the voters who participate make up a small, unrepresentative slice of the population eligible to vote. ${ }^{10}$ What results are elections that provide little guidance to elected officials on issues specific to the government in question, and do little to hold the governing coalition accountable for its performance.

What follows for law and legal scholarship? That is the question of Part III. The most important implication and the subject of Part III.A is that legal scholars and good-government reformers should start thinking about law's potential to influence the quality and availability of majorparty cues or their functional equivalents.

Ballots could, for example, "label" the existing partisan balance in government in addition to labeling candidates, thereby enabling retrospective voting by citizens who would otherwise be in the dark about which party is responsible for recent policy initiatives and social conditions. Party labels could be introduced into elections where they are currently missing, such as initiative and referendum elections, as well as nonpartisan state and local elections. And party labels could be modified to better distinguish the party at different levels of government, which may facilitate the development of locally differentiated party brands and make it easier for voters to see their content. To the same end, voter registration laws could be revised to make it easier for voters to change parties between local and national elections, encouraging localized rebranding from the bottom up.

But what of elections for governments as to which the major parties cannot be induced to develop well-tailored brands, or where the conven-

\footnotetext{
8. See infra Part II.B.

9. Id.

10. Id.
} 
tional party brands otherwise cause more harm than good (e.g., due to a severe imbalance of Michigan Voters)? Here we urge the removal of conventional party labels, in favor of party substitutes. We suggest two party-substitute cues that would approximate the desirable properties of well-calibrated major-party cues, and that could be printed on the ballot in formally nonpartisan elections.

The first of the party-substitutes, the executive cue, would signal endorsement by the most powerful elected official in the government at issue, e.g., the mayor or governor. Because of their visibility, mayors and governors can develop party-like personal brands. Labeling candidates for lower-profile offices on the ballot with the chief executive's endorsement would help voters to locate those candidates in the issue space of local politics.

Alternatively, states or cities could combine formally nonpartisan elections with a system of advisory open primaries designed to induce the formation of new party-like brands specific to subnational governments. Under the regime we envision, candidates would qualify for the ballot through a nonpartisan process, such as by submitting signatures from a certain number of registered voters. Political entrepreneurs would be invited to conduct advisory primary elections open to candidates and voters irrespective of their affiliation with official political parties. (In recognition of the open character of the advisory primaries, organizers would not be permitted to name their event after a political party with which voters have registered.) Candidates and voters would be limited to participating in one advisory primary per election cycle for the government in question. The winners of the two most popular advisory primaries, measured by the number of voters who opt in, would be designated as such on the ballot. This would lead to the development of a "twonotation system" in which the most popular advisory primaries function as de facto party cues calibrated to the government at issue.

As this preview makes clear, our prescriptions range from the simple to the fanciful, and are largely untested. We offer them not as a regimen for reform, but rather to illustrate how law might improve the performance of those elections most at risk due to voter ignorance, and to begin a conversation with legal scholars, political scientists, and policy entrepreneurs. Oddly enough, despite half a century's work on the problem of voter ignorance, political scientists have paid little attention to the effects of law on party branding, and to the possibilities for better labeling of ballots.

Whether election law can realize the meliorative function we ascribe to it will depend not only on the ingenuity of reformers, but also on the cooperation of the courts. The Supreme Court has curtailed public regulation of political parties through its "associational rights" jurisprudence. This body of law - our subject in Part III.B - expressly presumes that the ordinary voter is highly informed and engaged. Reasoning from 
that mistaken premise, the Court has declared that there is no legitimate state interest in trying to ensure that the major political parties establish and maintain ideologically coherent and electorally competitive brands. This cannot be right.

Part III.B concludes with some thoughts on what party-associational interests the First Amendment should be understood to protect. Parties, we suggest, should be treated as private associations with the designated public function of enabling a low-information electorate to steer public policy and hold the governing coalition accountable for results. On the approach we suggest, every citizen would have an interest in associating with any major political party, and no person or collectivity would have a privileged right to speak "on behalf" of the party. Courts would characterize burdens on political association by assessing whether the form of association sought by the plaintiff would further, or retard, the party's performance of its public function.

A caveat before proceeding: It is not our intention in this paper to provide a comprehensive overview of all the ways in which election law might mitigate or aggravate the voter-ignorance problem. We focus on parties and party labels because of their manifest importance and their history of regulation by law, but we certainly agree that there are other veins for legal scholars concerned with voter ignorance to mine. ${ }^{11}$

\section{VOTING WITHOUT (MUCH) INFORMATION: AN INTELLECTUAL HISTORY}

Two questions have anchored voting research for nearly half a century. Given a vast amount of evidence that voters lack much in the way of relevant factual knowledge of politics and policy, how do they make voting decisions? And what can we say about the quality of these decisions? This Part reviews the political science literature on voter competence and shows that the answers on offer are varied, rich, and full of disagreements. Some common points, however, appear. Voters benefit greatly from on-ballot tools, such as political party labels, that help them translate their policy preferences or retrospective evaluations into responsive votes. The aggregation of votes across large numbers of citizens can (but may not) yield coherent, seemingly well-informed outcomes even if most voters have little relevant knowledge. And partisanship is a bit of a double-edged sword: the organization of politics through political parties helps voters to infer what candidates are likely to do in office and makes the dominant governing coalition legible, but partisanship can also distort voters' factual perceptions and attributions of responsibility.

11. In a companion paper we mine some of these veins ourselves. See Christopher S. Elmendorf \& David Schleicher, Districting for a Low-Information Electorate, 121 YALE L.J. 1846 (2012). 


\section{A. "Constantly Bamboozled"? The American Voter As Political Ignoramus}

Contemporary critics of the American voter's ignorance have a long and illustrious lineage. In the first part of the twentieth century, the nation's two most prominent journalists-Walter Lippmann and H.L. Mencken-were savage in their treatment of the ordinary voter. "The individual man does not have opinions on all public affairs," wrote Lippman." "He does not know what is happening, why it is happening, what ought to happen." 13 Mencken was even more severe: "The American people, true enough, are sheep.... They are thus constantly bamboozled and exploited by small minorities of their own number, by determined and ambitious individuals, and even by exterior groups." 14

The great political theorist Joseph Schumpeter extended and refined this critique. In his classic work, Capitalism, Socialism and Democracy, Schumpeter broke with traditional democratic theory and denied the existence of a common will or even public opinion prior to political elites' contest for power. ${ }^{15}$ Citizens, he observed, have little incentive to learn about politics, in contrast to their strong monetary and social incentives to be good at their jobs. ${ }^{16}$ They are relegated by their lack of information to the essentially passive role of judging contests between political leaders, as opposed to forcing leaders to represent their pre-existing preferences. ${ }^{17}$ (Anthony Downs would formalize Schumpeter's incentives-and-information argument some years later. ${ }^{18}$ )

Schumpeter's conjecture about voter ignorance was not paired with systematic national evidence until the middle of the century, when University of Michigan political scientists developed nationwide surveys of voters, now known as the American National Election Studies. ${ }^{19}$ The results were collected in the landmark volume, The American Voter. ${ }^{20}$ "Our detailed inquiry into public attitudes regarding what we took to be the most prominent political issues of the time," the authors concluded, "revealed a substantial lack of familiarity with these policy questions. ... We have, then, the portrait of an electorate almost wholly without de-

\footnotetext{
12. Walter Lippmann, The Phantom Public 29, 29-55 (Transaction Publishers 1993) (1927).

13. Id.

14. H.L. MENCKEN, NOTES ON DEMOCRACY 78 (photo. reprint 1977) (1926).

15. JOSEPH A. SCHUMPETER, CAPITALISM, SOCIALISM, AND DEMOCRACY 251-68 (1942). Discussions of voter ignorance have been part of political theory at least as far back as Thucydides. THUCYDIDES, HISTORY OF THE PELOPONNESIAN WAR $\$ 6.1 .1$ (Rex Warner trans., 1954) (blaming the failure of the Athenian invasion of Sicily on voter ignorance).

16. SCHUMPETER, supra note 15 , at 258-60.

17. Id. at $262-68$.

18. ANTHONY DOWNS, AN ECONOMIC THEORY OF DEMOCRACY 238-60 (1957).

19. The Origins of the ANES, AM. NAT'L ELECTION STUD., http://www.electionstudies.org/ overview/origins.htm (last visited Feb. 19, 2013).

20. CAMPBELL ET AL., supra note 1, at 15-17.
} 
tailed information about decision making in government."'1

Since The American Voter, there have been countless surveys showing the ignorance of American citizens about politics and policy. Michael $X$. Delli Carpini and Scott Keeter pulled the key findings together in the mid-1990s. ${ }^{22}$ Their book is a horror-show of specifics. Here are some examples:

\section{Knowledge of Institutions and Processes}

- Only $55 \%$ of citizens know there are two senators from each state and only $25 \%$ know the length of a senatorial term

- $21 \%$ can define fiscal policy, $18 \%$ can define monetary policy, and $39 \%$ can define free trade

- $19 \%$ can name all three branches of government ${ }^{23}$

Knowledge of People and Players

- $35 \%$ could name both senators from their state

- $59 \%$ knew whether their governor was a Democrat or Republi$\mathrm{can}^{24}$

\section{Knowledge of Domestic Politics}

- $54 \%$ knew what the Watergate scandal was about in 1973

- $31 \%$ knew what Affirmative Action means ${ }^{25}$

Knowledge of Foreign Affairs

- $49 \%$ knew that the United States is the only country to have deployed a nuclear weapon

- $18 \%$ knew Israel was the largest recipient of U.S. aid in $1986^{26}$

Level of Knowledge within Selected Variable

- Only $21 \%$ can get within $10 \%$ of how much of the population has no health insurance

- Only $30 \%$ can get within $10 \%$ of how much of the federal budget is devoted to defense or Social Security ${ }^{27}$

There has been some criticism of such measures of voter knowledge, as they may be sensitive to the way questions are asked or to voters' ability to recall information quickly, rather than at all. ${ }^{28}$ Even so,

21. Id. at $542-43$.

22. Michael X. Delli Carpini \& SCOTt KeEter, What Americans Know About Politics AND WHY IT MATTERS 16-21 (1996).

23. Id. at $70-71$.

24. Id.at 74-75.

25. Id. at $80-81$.

26. Id. at 84 .

27. Id. at 93 .

28. See, e.g., James L. Gibson \& Gregory A. Caldeira, Knowing the Supreme Court? A Reconsideration of Public Ignorance of the High Court, 71 J. POL. 429, 430 (2009) (demonstrating greater 
few researchers believe that voters are anything other than poorly informed about politics and policy. ${ }^{29}$ Voter opinions about policy often diverge from those of experts who share the voter's ideology. ${ }^{30}$

U.S. politicians, however, behave as if they faced a somewhat informed populace. In speeches and in ads, politicians discuss facts that improved during their tenure in office (and mention facts that got worse during their opponents' tenure); they make policy arguments in political commercials; they change their positions in strategic ways, toward the extremes during primary campaigns and toward the center in general elections; and they generally attempt to appeal to voters through substantive (as well as nonsubstantive) political rhetoric.

It is hard to square this behavior among actors with a personal interest in winning votes with the largely unthinking picture of the electorate painted in survey data. It is equally difficult, though, to look at U.S. politics and imagine that voters are policy-obsessed wonks who somehow just test badly when asked political questions by researchers. Something else must be going on. Political scientists have spent the last fifty years trying to identify what that something else is.

\section{B. All in the Family: The American Voter and Party Identification}

One model of voters and parties has achieved dominance in legal scholarship. Developed by Anthony Downs, it posits that political parties compete by proposing policies along a right-to-left axis, and that voters select the candidate of whichever party comes closest to their preferences along the same axis. ${ }^{31}$ In a two-party race, the parties will converge as the party that wins the voter in the middle will have won fifty percent plus one of the votes, and hence the election. This is the famed median voter hypothesis. ${ }^{32}$

Downs's model fit with the dominant understanding of party behavior at the time, the Responsible Party Government (RPG) school. This project, which began with the work of Woodrow Wilson and Frank J. Goodnow at the turn of the twentieth century, reached its apex in the

knowledge of Supreme Court than conventional survey questions reveal); Markus Prior \& Arthur Lupia, Money, Time, and Political Knowledge: Distinguishing Quick Recall and Political Learning Skills, 52 AM. J. POL. SCI. 169, 170 (2008) (giving respondents more time improves answers to political information questions by eleven to twenty-four percent). But see Robert C. Luskin \& John G. Bullock, “Don't Know" Means "Don't Know": DK Responses and the Public's Level of Political Knowledge, 73 J. POL. 547 (2011) (showing with experiments that conventional survey items do not underestimate voters' working knowledge).

29. See, e.g., Somin, supra note 2, at 1305-06.

30. Bryan Caplan's fascinating book compared beliefs about economic issues and found that they were at odds with those of professional economists who share the voter's ideology and demographic profile. See BRYAN CAPLAN, THE MYTH OF THE RATIONAL VOTER: Why DEMOCRACIES CHOOSE BAD POLICIES 50-93 (2007).

31. DoWNs, supra note 18 , at 115-22.

32. Id.; Schleicher, Why, supra note 2, at 428-29. 
1950s in the work of Austin Ranney and E.E. Schattschneider. ${ }^{33}$ RPG scholars argued voters could only contribute to governance in a complicated modern democracy if political parties presented clear platforms and had enough internal coherence to bring them about upon winning control of the government. ${ }^{34}$ Such "responsible" parties were a precondition for meaningful voter participation, as large masses of people could never sift through the gamut of policy alternatives..$^{35}$ "The people are a sovereign whose vocabulary is limited to two words, 'Yes' and 'No."'36

But Downs and the RPG school still assumed a lot: that voters have well-formed policy preferences, that voters observe the policy outputs of government, and that voters make neutral assessments of facts and credit or blame the responsible governmental actors. ${ }^{37}$ Confidence in these assumptions took a blow with the publication of The American Voter.

The American Voter was-and probably still is - the single most important book ever written about voting in the United States. ${ }^{38}$ Marshaling the results of the first nationwide voter surveys, Angus Campbell, Phillip Converse, Warren Miller, and Donald Stokes concurred that parties are the key to voter decision making, but rejected the Downs/RPG hypothesis that voters choose their party on policy grounds. ${ }^{39}$ Rather, the voter of The American Voter is effectively tribal in his partisan allegiances. Partisanship is pre-political; a "psychological identification" more than an intellectual one. ${ }^{40}$ One's parents, most importantly, and later one's friends and social cohort, drive the decision to identify with a political party. ${ }^{41}$

33. For a history of the work on Responsible Party Government, see AuSTIN RANNEY, THE DOCTRINE OF RESPONSIBLE PARTY GovernMENT (1962). For its most famous distillations, see SCHATTSCHNEIDER, supra note 4; AM. POLmTICAL SCI. Ass'N, COMM. ON POlitical Parties, TOWARD A MORE RESPONSIBLE TWO-PARTY SYSTEM, at vii (1950).

34. See RANNEY, supra note 33 , at 9.

35. See SCHATTSCHNEIDER, supra note 4 , at 52 .

36. Id.

37. See Somin, supra note 2, at $1298-1300$

38. The American Voter drew on, but departed substantially from, the first substantial studies of voter behavior, done by scholars who have come to be known as the Columbia School. See BERNARD R. Bereleson et al., Voting: A STUdy of Opinion Formation In a Presidential CaMPaign (1954); Paul F. Lazarfeld ET Al., The PEOPle's Cholce: How the Voter MAKES UP His Mind IN A PREsidential CAMPAign (1944). Although largely similar in their findings to the Michigan School scholars who came later, the Columbia School emphasized the degree which social characteristics (income, gender, labor union membership, ethnicity, etc.) predict voting patterns, which interestingly caused pollsters to avoid late polling during the Truman-Dewey election of 1948 (and led to them getting the election wrong). See THEOdORE Rosenof, REALIGNMENT: ThE THEORY THAT Changed the Way We Think about American Politics 58-68 (2003). The American Voter differed from this by treating party membership as an independent social characteristic, like a religion itself.

39. CAMPBELL ET AL., supra note 1, at 542-44.

40. Id. at 121 .

41. Id. at $162-65$. One of our favorite recent papers addressed the finding that parental ideology had a strong effect on their children. Elias Dinas found that parental party identification is transmitted to children, but interestingly that the more politicized parents are, the less likely the child is to have the parents' ideology. The intuition is that parents both transmit a party identification and, con- 
Partisan ties once formed - "party identification" or "party ID" in the nomenclature of the book and henceforth in the political science literature-exert a powerful pull on voters' choices and even their opinions on issues. ${ }^{42}$ The American Voter found that party ID better predicted vote choice than the individual's assessment of the candidates. ${ }^{43}$ This was a stark discovery: people who identified as Republicans were more likely to vote for President Eisenhower than were people who said they had a favorable impression of President Eisenhower. ${ }^{44}$

The American Voter acknowledged that some people who identify with one party occasionally vote for candidates of another, but the vast majority vote the party line virtually all the time..$^{45}$ Only major realigning elections and social shifts change party identification. ${ }^{46}$ Party identification is the "unmoved mover" of everything else that happens in politics. ${ }^{47}$ Opinions on issues are largely epiphenomenal, a consequence rather than a cause of party identification. ${ }^{48}$

But what about vote switchers? The American Voter showed that the citizens most likely to support candidates of different parties from one election to the next were the least informed. ${ }^{49}$ This directly challenged the RPG view of elections as searching referenda on government performance. $^{50}$

sistent with stories discussed below, an interest in politics. Children from more political families update their preferences more often and, as a result, veer from parental party identification at a higher rate. Elias Dinas, The More You Try the Less It Sticks: Parental Politicization and the Endurance of Partisan Transmission Through the Family 3, 5 (APSA 2009 Toronto Meeting Paper), available at http://papers.ssrn.com/sol3/papers.cfm?abstract_id=1451307.

42. CAMPBELL ET AL., supra note 1, at 121 .

43. Id. at 74 .

44. Id.

45. Id. at 138-41 ("Of course, the influence of party identification on perceptions of political objects is so great that only rarely will the individual develop a set of attitude forces that conflicts with this allegiance.").

46. Id. at 151. This drew directly on arguments by Samuell Lubell and V.O. Key that there were "realigning" elections in American life. Samuel Lubell, The Future of American Politics (1952); V.O. Key, Jr., A Theory of Critical Elections, 17 J. POL. 3 (1955); V.O. Key, Jr., The Future of the Democratic Party, 28 VA. Q. REv. 161, 163-64 (1952). Elections during great periods of strife, like 1898 and 1932, did more than sweep one party into power; they set up patterns of voting that would last for decades. The American Voter provided a micro explanation for this macro theory-voters made up their minds and then party identification colored their votes and thoughts until their group identity was shaken by another titanic election. This led to a very long literature on what constituted a realigning election. For an excellent discussion of the idea of realignment, and The American Voter's role in it, see RoSENOF, supra note 38.

47. Thomas M. Carsey \& Geoffrey C. Layman, Changing Sides or Changing Minds? Party Identification and Policy Preferences in the American Electorate, 50 AM. J. POL. SCI. 464, 465 (2006) (characterizing The American Voter thus: "[P]arty identification is an 'unmoved mover:' a deeply held psychological attachment that is (1) largely unchanging over time even as events change, and (2) a filter through which citizens view and interpret new political information. From this perspective, party identification shapes policy preferences and other political attitudes, but is largely unchanged by them.").

48. Id.; Phillip Converse, The Nature of Belief Systems in Mass Publics, in IDEOLOGY AND DisCONTENT 206-56 (David E. Apter ed., 1964).

49. See CAMPBEll ET AL., supra note 1, at 143.

50. Id. 
The American Voter was (and is) a difficult pill to swallow for anyone committed to the democratic idea. But it made sense in context of its time..$^{51}$ Political parties in the 1950 s and early 1960 s were not nearly as coherent ideologically as parties today, ${ }^{52}$ yet the parties had intensely loyal followings nonetheless. ${ }^{53}$

\section{C. "A Reasonably Rational Fellow": The Running Tally, the Miracle of Aggregation, and Macropartisanship}

The American Voter dominated the field for more than twenty years, and it remains the central text for those studying voting behavior in the United States. ${ }^{54}$ Indeed, it was so dominant that, many years later, Morris Fiorina said he "distinctly remember[ed] a feeling of mild anxiety" when he first ran a regression with party identification as the dependent variable. ${ }^{55}$ But Fiorina pressed on and developed a model that attempted to reconcile the data in The American Voter with the work of Downs and the RPG school.

Fiorina argued that generally inattentive voters can develop a decent understanding of what parties do and stand for by incorporating their stray observations about politics and policy into a "running tally" assessment of the political parties. ${ }^{56}$ Party identification is simply a lifelong sum of the pluses and minuses a person observes about the performance of political parties. As long as the parties are consistent over time, one's running tally provides a serviceable guide to voting decisions. ${ }^{57}$ Fiorina's data showed that party identification and voting patterns moved over time, if slowly, and his theory provided an explanation for this finding. ${ }^{58}$

Far from the unquestioning ignoramus of The American Voter, the ordinary voter per Fiorina is "a reasonably rational fellow." 59 He does not know much about today's hot political issues, but his judgment about the political parties adds usefully to the project of self-governance. ${ }^{60}$ Christopher Achen formalized this model, arguing that the voter starts

51. It certainly reads like a document from the $1950 \mathrm{~s}$. Particularly, the dimestore Freudian analysis jumps off the page. "As the young adult passes through the early egocentric years, however, the salience that political matters have in his life gradually increases." Id. at 164.

52. See Sean M. Theriault, Party Polarization in Congress 24-27 (2008).

53. Norman H. Nie ET AL., The Changing American Voter 28-35 (1999).

54. See Morris P. Fiorina, Parties and Partisanship: A 40-Year Retrospective, 24 POL. BEHAV. 93, 97 (2002). The American Voter did face criticism from some prominent political scientists, notably V.O. Key. See V.O. Key, JR., The Responsible Electorate: Rationality in Presidential VOTING 1936-1960 (1966).

55. Fiorina, supra note 54 , at $98-99$.

56. MORRIS P. FIORINA, RETROSPECTIVE VOTING IN AMERICAN NATIONAL ElECTIONS, 89-105 (1981).

57. Id. at 83 .

58. Id. at 129 .

59. Id at 200.

60. See id. 
with her parent's preferences and updates them in a Bayesian fashion. The more observations she makes, the firmer her party identification. ${ }^{1}$ Achen's formalization proved that the stylized facts of The American Voter - the widespread lack of knowledge of today's issues, the consistency between the political beliefs of parents and children, the hardening of party identification over time, and the correlation between a lack of information and weak partisan attachments-were compatible with a world in which policy observations rather than group attachments are the key determinant of voting behavior. Experimental work by Milton Lodge and others added to the project by showing that voters exposed to campaign stimuli base their judgments on much more information than they can subsequently recall..$^{62}$ Survey-based measures of political knowledge miss the latent "tally" on which voters rely.

Fiorina's work highlights the importance of political parties and party labels for competent voting. It must be clear to voters which party is in charge so that they can link their policy-outcome observations to a party. Party positions and objectives must be reasonably consistent over time, so that the running tally actually differentiates the parties. Party labels must be assigned to candidates in a reliable fashion, lest voters be misled about what a candidate stands for. And the parties' endorsements must be known to the voter when she makes her decision. Clear and consistent party labels enable low-information voters to play a meaningful role in elections.

For our purposes, this is the key point: uninformed voters need tools in order to turn their retrospective (or prospective) policy evaluations into votes. And, as we argue in Part II, state and federal law determines the availability and quality of those tools.

Fiorina's model was not the only challenge to The American Voter consensus. $^{63}$ Samuel Popkin and Donald Wittman argued that voters get all sorts of politically relevant information from daily life, without a votemotivated search. Everything from buying gas to paying taxes exposes citizens to policy-relevant information, resulting in a better-informed

61. Christopher H. Achen, Parental Socialization and Rational Party Identification, 24 POL. BeHAV. 151, 153-67 (2002); Christopher H. Achen, Social Psychology, Demographic Variables, and Linear Regression: Breaking the Iron Triangle in Voting Research, 14 POL. BEHAV. 195, 200-04 (1992).

62. See, e.g., Milton Lodge \& Charles Taber, Three Steps Toward a Theory of Motivated Political Reasoning, in ELEMENTS OF REASON: COGNITION, CHOICE, AND THE BOUNDS OF RATIONALITY 183213 (Arthur Lupia et al., eds., 2000); Milton Lodge et al., The Responsive Voter: Campaign Information and the Dynamics of Candidate Evaluation, 89 AM. POL. SCI. REV. 309 (1995); Milton Lodge \& Ruth Hamill, A Partisan Schema for Political Information Processing, 80 AM. POL. SCI. REV. 505 (1986).

63. Notably, many books of this type came with extremely uncreative titles modeled on CAMPBELL ET AL., supra note 1. They read like a bad game of Mad Libs with the clue "The (Adjective) Voter." See, e.g., D. Sunshine Hillygus \& TODD G. ShIEldS, The Persuadable Voter: WEDGE Issues IN PRESIDENTIAL CAMPAIGNS (2008); NIE ET AL., THE CHANGING AMERICAN VoteR supra note 53; SAMUEl L. PoPKIN, THE REASONING Voter: COMMUNICATION AND PERSUASION IN Presidential CAMPaigns 22-26 (1994). Were we political scientists, this Article would surely be entitled, "The Legal Voter" or, if we only wanted to break out a little, "The Voter-In-Law." 
electorate than one would expect based on the instrumental value of voting. ${ }^{64}$ Stephen Ansolabehere, Jonathan Rodden, and James Snyder recently revisited the evidence of consistency and constraint in policy opinion. ${ }^{65}$ They argued that The American Voter's conclusions were likely due to measurement error, and that the simple corrective of measuring issue preferences by averaging across multiple survey items yields a picture of the ordinary voter as reasonably consistent and ideologically constrained in his policy opinions. ${ }^{66}$

Arthur Lupia and Mathew McCubbins deduced a series of propositions about how voters with little information about the issues could rely on cues provided by interest groups as well as parties. ${ }^{67} \mathrm{~A}$ rational citizen who understands the cue-givers' interests, informedness, and incentives for truth-telling can position herself between cues, as it were, and make decisions that are much like those of voters with detailed policy knowledge. ${ }^{68}$

Finally, much revisionist work has centered on the aggregate competence of the electorate. Benjamin Page and Robert Shapiro pointed out that bits of information that register with a few voters will nonetheless move mass opinion so long as unobservant voters stay constant in their views, or shift their views in some random, uncorrelated fashion. ${ }^{69}$ Moreover, the famed Condorcet Jury Theorem shows that a mass of individuals each of whom has only a slightly better than fifty-fifty chance of getting the right answer to a question will collectively get the answer right almost one hundred percent of the time, so long as the individuals act independently of one another. ${ }^{70}$ This has become known as the miracle of aggregation: acting together, even barely informed individuals can function as a well-informed collective.

64. See POPKIN. supra note 63, at 22-28; DONALD WITTMAN, THE MYTH OF DEMOCRATIC FAILURE: WHY POLITICAL INSTITUTIONS ARE EFFICIENT 11-12 (1995).

65. Stephen Ansolabehere et al., The Strength of Issues: Using Multiple Measures to Gauge Preference Stability, Ideological Constraint, and Issue Voting, 102 AM. POL. SCI. REV. 215 (2008).

66. Id. at 216; see also Boris Shor, All Together Now: Putting Congress, State Legislatures, and Individuals in a Common Ideological Space to Assess Representation at the Macro and Micro Levels 11-12 (Apr. 25, 2011) (unpublished manuscript), available at http://papers.ssrn.com/sol3/ papers.cfm?abstract_id=1697352 (using Bayesian ideal point estimation and surveys of voter policy preferences to show that public opinion is ideologically constrained, with a dominant first dimension).

67. Arthur lupia \& Mathew D. McCubbins, The Democratic Dilemma: Can Citizens LEARN WHAT THEY NEED TO KNOW? 69-77 (1998).

68. Id.

69. Benjamin I. Page \& Robert Y. Shapiro, The Rational Public: Fifty Years of TRENDS IN AMERICANS' POLICY PREFERENCES 15-26 (1992).

70. Id. at 26. Of course, Page and Shapiro note that the errors voters make are not uncorrelated. Correlated errors, however, do not destroy the Condorcet result but the more correlated vote patterns are, the better voters have to be on average. See Krishna K. Ladha, The Condorcet Jury Theorem, Free Speech, and Correlated Votes, 36 AM. J. POL. SCI. 617, 632 (1992). For a formal extension of the Condorcet Jury Theorem to majority rule in an electorate made up of competing groups, see Nicholas R. Miller, Information, Electorates, and Democracy: Some Extensions and Interpretations of the Condorcet Jury Theorem, in INFORMATION POOLING AND GROUP DECISION MAKING 173 (Bernard Grofman \& Guillermo Owen eds., 1986). 
Robert Erikson, Michael MacKuen, and James Stimson turned these insights into a massive research project on how the electorate processes political information. ${ }^{71}$ Acknowledging that most voters are uninformed and static in their preferences, Erikson et al. showed in The Macro Polity that the national electorate as a whole shifts partisan preferences in response to real-world political and economic events. ${ }^{72}$ Enough voters respond to political inputs for "macropartisanship" to resemble Fiorina-style updating, notwithstanding that many voters are Michigan types.

Fiorina and the aggregation literature created a clear micro- and macro-level theory that could restore a general faith in democracy, despite widespread voter ignorance of politics. Their work since has come under fire, as the next Section explains. Regardless of who is right, though, their work reflected its times much as The American Voter spoke of its own. Voters in the highly-charged world of the late 1960s and 1970s seemed more informed and inflamed by politics than in the staid 1950s. The parties were also weaker, particularly after Watergate, with party-line voting in Congress falling to all-time lows and candidatecentered campaigns on the rise. ${ }^{73}$ Research on voting followed suit, treating voters not as blind partisans but, particularly in the aggregate, as rationally responsive to events and policy decisions. The world, however, did not stand still, and neither did the literature.

\section{D. "Partisan Hearts and Minds": Dissent from the Running Tally and Macropartisanship}

If the 1970s was a period of decline for parties and partisanship inside legislatures and among voters, the recent era has seen an enormous revival. In a trend that started in the 1980 s, the parties became more ideologically distinct from one another, party-line voting in Congress became more consistent, and voters became less likely to vote against their long-run party identification or to split their tickets. ${ }^{74}$ This change in experience has been matched by a change in views, with political scientists and economists attacking the "voter [or electorate] as a relatively reasonable fellow" synthesis of the 1980 s. $^{75}$

Larry Bartels challenged the miracle of aggregation by documenting gaps between the actual vote shares of presidential candidates and the vote shares one would expect from a well-informed electorate. ${ }^{76}$ (He cal-

71. ROBERT S. ERIKSON ET AL., THE MACRO POLITY (2002).

72. Id. at 117-24, 230-35.

73. Fiorina, supra note 54, at 94-99.

74. Id. at 99-103; MatTHEW LeVENDUSKY, THE PARTISAN SORT: How Liberals BeCAME Democrats And Conservatives BeCAME Republicans 1-2 (2009); Larry M. Bartels, Partisanship and Voting Behavior, 1952-1996, 44 AM. J. POL. SCI. 35, 44 (2000).

75. See KEY, supra note 54 , at 40.

76. Bartels, supra note 6. 
culated the latter using the reported votes of high-knowledge individuals and normalizing for population traits. ${ }^{77}$ ) Donald Green, Bradley Palmquist, and Eric Shickler went after the statistical underpinnings of The Macro Polity; their models suggest that macropartisanship is much less responsive to economic conditions and public policy. ${ }^{78}$ This occasioned an impassioned response from the authors of The Macro Polity. ${ }^{79}$ The debate is ongoing and feverish.

The assumptions behind the micro- and macro-stories about voter competence also have been challenged. The optimists supposed that voters independently and fairly assess whatever new information they acquire and attribute policies and policy results to the proper politicians or institutions. ${ }^{80}$ But party identification affects voters' perceptions of the facts. For instance, many voters of both parties got the answer wrong when asked whether the budget deficit increased or decreased during Bill Clinton's eight years in office (it decreased a lot) but there was a systematic partisan difference, with fifty-two percent of Republicans thinking it increased, compared with thirty-two percent of Democrats. ${ }^{81}$ The same thing in reverse was true for evidence of reduced unemployment and inflation under Reagan. ${ }^{82}$ Further, shocks to partisan affiliation affect issue stances, with voters who became Democrats after Watergate becoming more liberal across a range of issues. ${ }^{83}$ Rather than adding information neutrally to running tallies, voters conform their beliefs to their partisan identification. They have, as Green and his co-authors put it, "partisan hearts and minds." 84

They are also shortsighted. Presidents facing reelection are assessed largely on income growth during the election year (and to a lesser degree on income growth during the year before the election year) and not at all on income growth in the first two years of a presidency. ${ }^{85}$ Some discounting of the early part of a presidential term may be warranted, but failing to take it into account at all is myopic.

Finally, voters often lack the basic information about institutional

77. That is, he showed that low-information voters with given demographic traits (class, race, religion, etc.) voted differently from high-information voters with the same demographic traits. Id. at 206.

78. Donald Green et al., Partisan Hearts and Minds: Political Parties and the SOCIAL IDENTITIES OF VOTERS, at vii-viii, 85-108 (2002).

79. ERIKSON ET AL., supra note 75, at 142-45; Robert S. Erikson et al., What Moves Macropartisanship? A Response to Green, Palmquist, and Schickler, 92 AM. POL. SCI. ReV. 901 (1998).

80. See PAGE \& SHAPIRO, supra note 69, at 383-90; Popkin, supra note 63, at 31.

81. See Larry M. Bartels, Beyond the Running Tally: Partisan Bias in Political Perceptions, 24 Pol. Behav. 117, 134 (2002); Christopher H. Achen \& Larry M. Bartels, It Feels Like We're Thinking: The Rationalizing Voter and Electoral Democracy 12-13 (Aug. 28, 2006) (unpublished manuscript), available at http:/www.princeton.edu/-bartels/papers.

82. Bartels, supra note 81 , at 134.

83. Achen \& Bartels, supra note 81 , at $29-31$.

84. GREEN ET AL., supra note 78.

85. Larry M. Bartels, Unequal Democracy: The Political Economy of the New GILDED AGE 100-04 (2008). 
responsibility and political control required for running-tally decision making. For instance, a poll taken immediately after the 2002 election revealed that only a third of all Americans knew that Republicans had controlled the House of Representatives prior to the election. ${ }^{86}$ And knowledge of party control without knowledge of responsibilities isn't much help-it could result (for example) in voters blaming the President for unemployment caused by the Federal Reserve. ${ }^{87}$ When voters credit or blame politicians for events beyond their control, both individual and aggregate running tallies become pointlessly volatile.

Using a variety of natural experiments, political scientists and economists have demonstrated that people lay credit or place blame on elected officials for all sorts of exogenous events. Voters in oil-producing states give governors credit for increases in the world price of oil, even though there is no plausible argument that gubernatorial policies affect the global oil market. ${ }^{88}$ State-level incumbents generally benefit from national economic booms. ${ }^{89}$ Conversely, incumbents pay a price for such random adversities as shark attacks, ${ }^{90}$ floods, ${ }^{91}$ and tornadoes. ${ }^{92}$ A particularly entertaining study documents the combined effect of myopia and misattribution: incumbents get a significant boost when the home team wins a college football game the Saturday before an election..$^{93}$

Yet a closer look at these studies reveals that voters are less hapless than they first appear. Voters give state politicians less credit for national and international booms than local ones, and voters "show partial success in not attributing blame for economic downturns to governors during national recessions." "[a]rguably ... as successful at this task as corporate boards are when setting CEO compensation."95 Following floods, voters are highly sensitive to the success of relief efforts, with incumbents faring far better

86. Somin, supra note 2, at 1305.

87. DELLI CARPINI \& KEETER, supra note 22, at 69-71 (finding that voters lack much knowledge about legislative and political processes).

88. Justin Wolfers, Are Voters Rational? Evidence from Gubernatorial Elections (Jan. 30, 2007) (unpublished manuscript), available at $\mathrm{http} / /$ ideas.repec.org/p/ecl/stabus/1730.html.

89. See Andrew Leigh \& Mark McLeish, Are State Elections Affected by the National Economy? Evidence from Australia, 85 ECON. REC. 210 (2009).

90. Christopher H. Achen \& Larry M. Bartels, Blind Retrospection: Electoral Responses to Drought, Flu, and Shark Attacks (Estudio Working Paper, 2004/199, 2004), available at http://www.allacademic.com/meta/p65097_index.html.

91. Shawn A. Cole et al., Do Voters Appreciate Responsive Governments? Evidence from Indian Disaster Relief, (Harvard Bus. Sch. Working Paper, No. 09-050, 2008), available at http://papers.ssrn.com/sol3/papers.cfm?abstract_id=1276339.

92. Andrew Healy \& Neil Malhotra, Random Events, Economic Losses, and Retrospective Voting: Implications for Democratic Competence, 5. Q.J. POL. SCI. 193 (2010).

93. Andrew J. Healy et al., Personal Emotions and Political Decision Making: Implications for Voter Competence 2 (Stanford Graduate School of Business Research Paper No. 2034, 2009), available at https://gsbapps.stanford.edu/researchpapers/detail1,asp?Document_ID=3269.

94. Wolfers, supra note 88 , at 2 .

95. Id at 1 . 
when they respond well to the crisis. ${ }^{96}$ Voters reward disaster relief spending on tornados, with strong responses leaving politicians better off than if no tornado had occurred..$^{97}$

Even the overwhelming recent polarization of political parties has been given a soft rationalist spin. In his recent book, The Disappearing Center, Alan Abramowitz argued that although most citizens are centrist in their beliefs, most engaged voters are not, and political leaders are responsive to the engaged part of the electorate. ${ }^{98}$ The increased polarization among regular voters reflects a greater correlation between education and political participation; educated voters are more likely to have ideologically coherent preferences. ${ }^{99}$ Meanwhile, the emergence of stark party-based differences in candidate positioning has increased turnout and made voting decisions easier (as predicted by the RPG scholars). ${ }^{100}$ Far from being a sign of irrationality, polarization per Abramowitz is both a consequence and a cause of increased voter rationality. ${ }^{101}$

The latter point is backed up by Richard Lau and David Redlawsk's work on "correct voting" in presidential elections. ${ }^{102}$ Lau and Redlawsk use experimental and econometric techniques for determining whether stated voter preferences about issues match voter preferences about candidates. They code a candidate preference as incorrect when it contradicts the voter's issue preferences. Voters frequently support the wrong candidate, as many as forty-nine percent in some presidential years. ${ }^{103}$ The last election, however, in Lau and Redlawsk's study-heavily polarized 2004-was the best ever for correct voting, suggesting that clear choices can help voters overcome their ignorance. ${ }^{104}$

Who has gotten the better of the debate between running-tally and macropartisanship scholars and their critics is still somewhat in question, but a middle ground seems to be emerging. Some recent work suggests that voters' partisanship tracks their (prior) policy preferences on the issues most salient to them, whereas party ID determines policy preferences on low-salience issues. ${ }^{105}$ The American Voter Revisited, a recent

\footnotetext{
96. Cole et al., supra note 91 , at 3 .

97. Andrew J. Healy \& Neil Malhotra, Myopic Voters and Natural Disaster Policy, 103 AM. POL. SCI. REV. 387, 387-88 (2009). This has its own pathologies, however, as voters reward disaster relief spending, but not spending on disaster prevention.

98. Alan I. ABramowitz, The Disappearing Center: Engaged Citizens, Polarization, \& AMERICAN DEMOCRACY 34-57 (2010).

99. Id. at $120-27$.

100. Id. at $158-60$.

101. See id. at $120-27$.

102. Richard R. Lau et al., An Exploration of Correct Voting in Recent U.S. Presidential Elections, 52 AM. J. POL. SCI. 395, 396-98 (2008); Lau \& Redlawsk, supra note 6.

103. Lau et al., supra note 102 , at 401.

104. Id. They find an ongoing correlation between candidates' distinctness from one another and "correct" voting. Id. at 407; see also David R. Jones, Partisan Polarization and Congressional Accountability in House Elections, 54 AM. J. POL. SCI. 323, 325 (2010) (finding that party polarization is correlated with retrospective voting in Congressional elections).

105. See Carsey \& Layman, supra note 47, at 464; see also Benjamin Highton \& Cindy D. Kam,
} 
volume dedicated to the original authors, suggests that the "unmoved mover" theory of partisan identification misses something, although partisan identification is still quite sticky. ${ }^{106}$ Fiorina has joked,

the debate has struck me as reminiscent of the classic anecdote, the punchline of which is 'Madame, we are only quibbling about the price'.... [E]ven if 1980-ish statistical estimates of the responsiveness of individual-level party ID ultimately prove to be too high, the 1990 s critiques fall short of convincing me that party ID is an unmoved mover. . . Party ID may move slowly, but it moves. ${ }^{107}$

Without resolving this internecine battle, we can draw a few lessons. Voters make mistakes, both individually and in the aggregate. They overrate the importance of recent periods, give politicians credit for the wrong things, view facts through a partisan lens, and have some simply outlandish opinions. The electorate is, however, nonetheless capable of providing useful feedback when armed with clear party labels (and perhaps other heuristics) that are consistent over time and available at the moment of decision. ${ }^{108}$ Equipped with good tools, the electorate looks responsive, if human, in its failings. This makes sense when you consider how candidates and parties behave, generally treating the electorate like it is a reasoning body, but also feeding its rationalizing (and just strange) sides.

\section{E. So What?}

The political science of voter ignorance has engendered two kinds of normative claims or projects. One consists of lamentations or celebrations of how well democracy works. ${ }^{109}$ The other takes the form of prescriptions to minimize the continued significance of ordinary elections through sweeping constitutional reforms ${ }^{110}$ or heroic voter education pro-

The Long-Term Dynamics of Partisanship and Issue Orientations, 73 J. POL. 202 (2011); Rune Slothuus, When Can Political Parties Lead Public Opinion? Evidence from a Natural Experiment, 27 POL. COMM. 158 (2010).

106. Michael S. Lewis-Beck et Al., The American Voter Revisited 134-35 (2008). The book is amusingly organized to replicate the chapter structure of The American Voter, much like Liz Phair's brilliant album Exile in Guyville matched the tracks of The Rolling Stones's Exile on Main Street. See Greg Kot, Return to 'Exile'; Liz Phair Takes to Stage As Her Once-Controversial Classic 'Exile in Guyville' Is Reissued, CHI. TRIB., June 22, 2008, at C6 (noting that Phair described Exile in Guyville as a track-by-track response to Exile on Main Street).

107. Fiorina, supra note 54, at 98-99; see also Bartels, supra note 6, at 194 (finding that aggregation reduces but does not eliminate deviations of actual vote from fully informed vote).

108. The importance of printing the label on the ballot itself-making it available to lowinformation voters at the moment of decision-becomes clear when one examines the performance of nonpartisan elections. See infra Part II.A.1.

109. Contrast the happy optimism of The Macro Polity with Larry Bartels's finding that U.S. Senators are completely unresponsive to the issue preferences of their poor constituents. See BARTELS, supra note 85, at 101-15; ERIKSON ET AL., supra note 71.

110. Exemplars include Ilya Somin's fascinating series of arguments for smaller federal government and aggressive judicial enforcement of rights with little concern for the "countermajoritarian difficulty," and Ethan Leib's proposal for a new "popular branch" of government modeled on the jury. 
jects. ${ }^{111}$ The common theme in all these works is that the authors, groping for alternatives to the status quo, spend little time examining where elections work comparatively well or poorly under the status quo.

Judgments about "whether democracy works," given what voters know, are both irreducibly normative and hard to make. The political science literature does, however, enable one to form reasonable conjectures about which elections are likely to work relatively well or comparatively poorly. (Like many political scientists, we treat elections as performing well insofar as they yield outcomes that resemble those that would have resulted in a world of high-information, policy-andperformance minded voters.) Once one sees the variation across elections and its likely causes, it becomes possible to identify small-bore policy reforms that show promise for improving the performance of those elections most at risk of going awry due to voter ignorance. This is the argument we develop in Parts II and III of this Article. Our central contention is that law plays a tremendously important role in determining whether everyday elections perform ordinarily well. This point has largely escaped the notice of political scientists and law professors alike.

\section{ELECTIONS AT RISK}

The last Part surveyed the debate over how (and how well) voters make decisions without much specific knowledge about policies and politics. As we saw, there is much disagreement about how voters behave, how they process information, and the extent to which heuristics, like party labels on the ballot, enable voters to reliably translate their observations into electoral feedback. But the canonical works have one important commonality: they focus on national politics and elections. The circumstances of national elections are comparatively propitious for informed voting. In national elections, voters have party labels on the ballot that correspond to the main ideological divisions within the electorate, that are associated with high-profile figures like the President, and that are reasonably consistent over time. ${ }^{112}$ Elections that will determine the presidency or control of Congress also receive relatively intense media coverage. ${ }^{113}$ And candidates and outside groups spend huge

Ethan J. LeIb, Deliberative Democracy in America: A Proposal for a Popular Branch of GOVERNMENT (2004); Somin, supra note 2; llya Somin \& Neal Devins, Can We Make the Constitution More Democratic, 55 DRAKE L. REv. 971 (2007).

111. See, e.g., BRUCE ACKERMAN \& JAMES S. Fishkin, DelibERATION DAY (2004).

112. See generally ABRAMOWITZ, supra note 98, at 84-120 (discussing increasing partisanideological polarization).

113. See, e.g., Martin Kaplan et al., Lear Ctr. Local News Archive, Local News Coverage of THE 2004 CAMPAIGNS: AN ANALYSIS OF NIGHTLY BROADCASTS IN 11 MARKETS 1011, 29 (2005), available at http://www.localnewsarchive.org/pdf/LCLNAFinal2004.pdf (finding, in study of local television coverage in 2004, that sixty-one percent of campaign stories were devoted to the presidential race, while about one percent were devoted to state legislative races). Media coverage affects the extent of voter ignorance. See Christopher Berry \& William Howell, Accountability and 
sums of money to get their messages across. ${ }^{114}$ All of these factors help voters to link their policy preferences and their observations of the world around them to the choices they make in the voting booth.

This Part shows that the prospects for aggregate voter competence in many other American elections are far worse. We argue, moreover, that these elections suffer in part due to the choices states have made in regulating the electoral process. Voter competence is endogenous to election law.

This is so because election law influences both the availability and the quality of party cues. Some elections are required by law to be "unlabeled," i.e., conducted without political party designations on the ballot, and as Part II.A explains, the available evidence suggests that these elections work poorly. Initiative and referendum elections, most local government elections, and primary elections fall into this category.

In other elections parties are present but dysfunctional, either because they are substantively "mismatched" to the issue space and electorate for the government in question, because Bayesian voters do not see the party brands in terms of their local content, or because an imbalance of Michigan types essentially predetermines which party will control the government. These problems seem to plague some state and many local government elections. Though they are not at first glance legal problems, we will argue that law has considerable potential to exacerbate or ameliorate them.

\section{A. Elections Without Party Brands: Nonpartisan, Primary, and Direct Democracy Elections}

Political scientists have studied the performance of nonpartisan elections, primary elections, and ballot-initiative and referendum elections. What they have found largely confirms the hypothesis that party cues play an absolutely central role in enabling citizens to choose ideologically congenial candidates, and to hold the government accountable for performance.

\section{Nonpartisan Elections}

The laws governing many state and local elections bar any reference to political parties on the ballot. Nearly seventy percent of American cities have nonpartisan elections, as do almost all other local governing bodies, like school boards. ${ }^{115}$ A majority of judicial elections are nonpar-

Local Elections: Rethinking Retrospective Voting, 69 J. POL. 844, 845 (2007) (finding that voters in school board elections took student performance metrics into account when they were heavily covered in the media, but not when media coverage had died down).

114. Total spending in the 2008 election was more than $\$ 3$ billion. Editorial, Letting Big Money In, PHIL. INQ., Nov. 8, 2009, at C4.

115. See Chandler Davidson \& Luis Ricardo Fraga, Slating Groups As Parties in a "Nonpartisan" 
tisan, ${ }^{116}$ and a number of other state officials around the country are elected on a formally nonpartisan basis, ranging from the entirety of the unicameral Nebraska legislature ${ }^{117}$ to the California State Superintendent of Public Instruction. ${ }^{118}$

Virtually everything we know about these races indicates that voters are harmed by the lack of relevant party information. Turnout is lower in nonpartisan elections, and incumbents are stronger, suggesting that informed voting is costly and voters rely more on name recognition and familiarity when denied information about party. ${ }^{119}$ Voters deprived of easy access to partisan cues also give much more weight to candidates' race, ethnicity, religion, and social status. ${ }^{120}$

Voters in formally nonpartisan elections do respond to evidence of candidates' party membership -if they find out about it. For example, if voters learn which governor appointed a judge facing a retention election, that signal of partisanship becomes the only variable that has a discernible effect on the election. ${ }^{121}$ Local political party organizations in some cities make and disseminate candidate endorsements, ${ }^{122}$ but many voters don't hear the message. Minority parties consistently outperform in nonpartisan elections, garnering more votes than would be expected based on the fraction of the electorate that identifies with the party. ${ }^{123}$ This is the predictable consequence of holding elections under circumstances in which a large fraction of voters are likely to make the wrong

Setting, 41 WEST. POL. Q. 373 (1988).

116. Steven P. Croley, The Majoritarian Difficulty: Elective Judiciaries and the Rule of Law, $62 \mathrm{U}$. CHI. L. REV. 689, 725 (1995).

117. Gerald C. Wright \& Brian F. Schaffner, The Influence of Party: Evidence from the State Legislatures, 96 AM. POL. SCI. REV. 367 (2002).

118. Brian F. Schaffner \& Matthew J. Streb, The Partisan Heuristic in Low-Information Elections, 66 PUB. OPINION Q. 559 (2002).

119. Id. at 579 (comparing partisan and nonpartisan elections for statewide office); Brian Schaffner et al., Teams Without Uniforms: The Nonpartisan Ballot in State and Local Elections, 54 POL. RESEARCH Q. 7, 7-25 (2001) (finding in legislative races that in most cases turnout falls and in all cases the effect of incumbency increases).

120. Gerald C. Wright, Charles Adrian and the Study of Nonpartisan Elections, 61 PoL. RES. Q. 13, 13-16 (2008); see also Phillip L. Dubois, Voting Cues in Nonpartisan Trial Courts: A Multivariate Assessment, 18 LAW \& SOC'Y REV. 395, 430-31 (1984); Marsha Matson \& Terri Susan Fine, Gender, Ethnicity, and Ballot Information: Ballot Cues in Low-Information Elections, 6 STATE POL. AND PolicY Q. 49 (2006); Peverill Squire \& Eric R.A.N. Smith, The Effect of Partisan Information on Voters in Nonpartisan Elections, 50 J. PoL. 169, 173-74 (1988). Regarding racial voting cues in nonpartisan elections, see Christopher S. Elmendorf, Making Sense of Section 2: Of Biased Votes, Unconstitutional Elections, and Common Law Statutes, 160 U. PA. L. REV. 377, 443-44 (2012) (citing and describing studies).

121. Squire \& Smith, supra note 120, at 177; see also Cindy D. Kam, Implicit Attitudes, Explicit Choices: When Subliminal Priming Predicts Candidate Preference, 29 POL. BEHAV. 343, 344-45 (2007) (reporting experimental results showing that introduction of party cue into judicial retention elections negates the effect of implicit and explicit racial biases on vote choice).

122. See, e.g., Timothy B. Krebs, The Determinants of Candidates' Vote Share and the Advantages of Incumbency in City Council Elections, 42 AM. J. POL. SCI. 921, 923 (1988) (mentioning the role of the Democratic Party in formally nonpartisan Chicago elections).

123. Brian F. Schaffner et al., A New Look at the Republican Bias in Nonpartisan Elections, 60 POL. RES. Q. 240, 240 (2007). 
choice relative to their underlying preferences.

The correlation between what candidates say when running for office and how they vote if elected is also weaker in the case of legislatures elected on a nonpartisan basis. "Nonpartisan" legislators don't act as if they were worried about ideological challengers who might hold their feet to the fire, which is no surprise given the powerful incumbency advantage in nonpartisan elections. ${ }^{124}$

Nonpartisan elections also hinder retrospective voting because they obscure the identity of the dominant coalition (if there is one) in the legislative body, and because they deprive voters of a simple, ballot-based indicator of whether a given candidate would join the dominant coalition or work against it. As two leading researchers put it: "[N]onpartisan elections effectively break the policy linkage between citizens and their representatives." ${ }^{125}$

Seth Masket's penetrating study of California legislative elections during the era of "cross filing" well-illustrates the problem. ${ }^{126}$ From 1910-1952, California permitted candidates to seek the nomination of more than one political party, and did not require candidates to list their party affiliation on the primary ballot. ${ }^{127}$ Incumbent legislators regularly sought, and won, the nomination of both political parties. The legislature during this era was unproductive and corrupt. Powerful, well-organized interests such as liquor distributors were well served, but broad ideological visions left no mark on policy. Disappointed by the legislature's failure to adopt progressive New Deal policies, unions eventually turned to the ballot initiative to force candidates' party affiliation to be printed on the primary ballot. ${ }^{128}$ This seemingly trivial reform had sweeping consequences. Primary voters quit nominating other-party incumbents. Lawmakers started facing general election competition. And the California legislature soon looked, and behaved, like a normal legislature organized on party lines.

What is striking about Masket's story is not only that legislative indolence and graft flourished in the absence of party-enabled retrospective accountability, but also that the mass electorate was unable to figure out the most rudimentary indicator of even incumbents' ideological orientation - their party affiliation - until it was printed on the ballot. ${ }^{129}$

124. Wright \& Schaffner, supra note 117 , at $375-77$.

125. Id. at 377.

126. Seth E. Masket, No Middle Ground: How Informal Party Organizations CONTROL NOMINATIONS AND POLARIZE LEGISLATURES 55-86 (2009).

127. Id. at 58-59.

128. Id. at 73 .

129. To be sure, cross-filing had the effect of depriving party brands of much of their ideological content. But the brands clearly retained some ideological content, as evidenced by the changes that followed the reintroduction of party labels. 


\section{Primary Elections}

Although cross-filing is not to our knowledge permitted in any state legislative elections today, the problem of voter ignorance in primary elections remains. The standard primary election is just a nonpartisan election conducted with party-based restrictions on who may participate as a candidate or voter. The exclusion of other-party candidates suffices to avoid the farce that was California during the era of cross-filing, but it does not help voters to make an informed choice among candidates willing to affiliate with the party. And the available evidence suggests that primary elections are at best a weak mechanism for selecting candidates who are proximate to the median primary voter on the issues. ${ }^{130}$

Much of what is known about primaries owes to research on congressional elections, where voters are likely to be better informed than in state or local primaries. Even so, the results cast serious doubt on the idea that primaries are meaningful vehicles for representing eligible voters' policy preferences. ${ }^{131}$ A massive survey of the ideological position of House candidates from 1874 to 1996 concluded that virtually all candidate positioning was determined by the national parties, "moderating very little to accommodate local ideological conditions." 132 Other empirical work suggests primary competition does not much affect the propensity of Members of Congress to take extreme positions, i.e., to placate their base. ${ }^{133}$ And the form of the primary is not very consequential. Despite the conventional wisdom of the cognoscenti, there is little evidence that using open primaries (in which independents may vote) or closed primaries (which limit participation to party members) has any consistent effect on legislator behavior. ${ }^{134}$ Although there is some evidence that goes the other way, particularly as to congressional districts whose boundaries correspond to major media markets, ${ }^{135}$ most research shows

130. Whether primaries are better for selecting candidates than the familiar alternatives-e.g., caucuses, smoke-filled backrooms - is a separate question and one we do not address. We only mean to suggest that primaries do not do much to bring candidate positioning or official performance in line with median party member preferences. This is a point that has important implications for legal academics' long-running debate over bipartisan gerrymandering. See Elmendorf \& Schleicher, supra note 11.

131. Notably, there has also been a substantial decline over the last seventy or so years in the number of primaries in seats featuring incumbents in both the Senate and the House. Stephen Ansolabehre et al., More Democracy: The Direct Primary and Competition in U.S. Elections, 24 STUD. IN AM. POL. DEV. 190, 196-99 (2010).

132. Stephen Ansolabehere et al., Candidate Positioning in U.S. House Elections, 45 AM. J. POL. SCI. 136, 136 (2001). In periods where the party system is less strong, candidates take ideological positions that fit their districts to a greater degree. Id.

133. Id. at 153; ERIC MCGHEe, PUB. POL. INST. Of CA., OPEN PrIMARIES (2010); Shigeo Hirano et al., Primary Competition and Partisan Polarization in the U.S. Congress, 5 Q. J. POL. SCI. 169 (2010); available at http://www.ppic.org/main/publication.asp? $\mathrm{i}=904$.

134. Eric McGhee et al., A Primary Cause of Partisanship? Nomination Systems and Legislator Ideology (Oct. 20, 2011) (unpublished manuscript), available at http://papers.ssm.com/sol3/ papers.cfm?abstract $i d=1674091$.

135. See, e.g., Kathleen Bawn et al., A Theory of Political Parties, 10 Perspectives ON Pol. 571, 
that the partisan makeup of a district has only a weak effect on the ideological voting patterns of representatives, beyond determining which party wins the seat.

In keeping with this finding, the authors of a painstaking study of the content of House primary campaigns since 1970 discovered that a huge majority of (increasingly rare) primary challenges to incumbents had no ideological content at all. ${ }^{136}$ They centered instead on ethical or corruption scandals, the age of the incumbent, ethnic or geographic conflict inside a district, or redistricting.

Even when ideological competition occurs, there is little reason to expect it to yield a nominee who represents the preferences of most members of the party. There is a long-standing belief (although a disputed one) among political scientists that primary electorates are more extreme than ordinary party members, providing an advantage to more radical candidates. ${ }^{137}$ To the extent it is true, this effect simply illustrates a larger phenomenon inside primaries-whoever can get organized and get voters to the polls wins. Masket has shown that candidates promoted by strong in-party interest groups and factions dominate primary elections. ${ }^{138}$ Some of these groups are ideological, like the Lincoln Club, a group of conservative Republicans in Orange County who organize to elect the most conservative candidate possible in each district; others are more personal machines, like the Allatorre-Torres machine on the Eastside of Los Angeles or Maxine Waters's organization in South Los Angeles. ${ }^{139}$ In either case, it is their organizational muscle rather than their appeal to average voters in the district that counts.

The failures of primary elections are due to the fact that ordinary party members lack the tools-specifically on-ballot heuristic guides to candidates' issue stances and the performance of party factions - to turn primary elections into meaningful instances of democratic control.

579-81 (2012) (showing that media-market congruence has a substantial effect on probability that moderate congresspersons will be defeated in primary election); David W. Brady et al., Primary Elections and Candidate Ideology: Out of Step with the Primary Electorate?, 32 LEG. STUD. Q. 79 (2007) (showing, in a study of U.S. House of Representative primary and general elections from 1958-1998, that primary electorates favor more ideologically extreme candidates than the general-election electorate, and that candidates generally respond by positioning themselves closer to the primary electorate median); Marty Cohen et al., Without a Watchdog: The Effect of Local News on Political Polarization in Congress (2004) (Paper presented at the Annual Meeting of the American Political Science Association) (showing that effect of district partisanship on Member of Congress ideological position is strongly conditioned by newspaper coverage, and, somewhat more weakly, by congruence between congressional district shape and local media markets).

136. Robert G. Boatright, Getting Primaried: The Growth and Consequences of Ideological Primaries 25 (October 16, 2009) (unpublished manuscript), available at http://www.clarku.edu/ departments/politicalscience/pdfs/boatright_sotp09.pdf.

137. See V.O. Key, American State Politics: An InTRoduction 153 (1956) (arguing that primary electorates are more ideologically extreme than party members generally). But see Austin Ranney, The Representativeness of Primary Electorates, 12 MIDWEST J. POL. SCI. 224, 224 (1968) (challenging this view).

138. MASKET, supra note 126 , at 8-10.

139. Id. at 116-29. 
Where primary elections constitute the only check on government performance (i.e., in one-party cities and states), accountability and responsiveness will suffer.

\section{Direct Democracy Elections}

Initiative and referendum elections pose extraordinary challenges for ordinary voters. ${ }^{140}$ In nonpartisan representative elections, citizens deprived of the party label may rely instead on character judgments, or on the candidates' position-taking with respect to a small number of policies about which the voter has well-formed beliefs, or on the candidates' social-group or religious identities. Not so in initiative and referendum elections, where the choice to be made is whether to enact a law (which may address anything under the sun) rather than to elect a person. Worse, initiative voters are asked to make these choices in an environment that discourages attention to tradeoffs and policy alternatives. ${ }^{141}$

Worries about voter competence in direct democracy are longstanding. ${ }^{142}$ In the late $1990 \mathrm{~s}$, however, some political scientists developed a revisionist and more optimistic outlook. The optimists' story draws on several lines of research. One, on the logic and practice of voting based on interest-group cues, ${ }^{143}$ establishes that credible cues can in theory substitute for a detailed understanding of policy; ${ }^{144}$ that voters self-report following elite cues, ${ }^{145}$ and that the patterns of self-reported cue usage make sense given respondents' stated party affiliations (e.g., Democrats follow labor cues, and Republicans follow anti-tax cues). ${ }^{146}$ The second line of research consists of case studies of prominent initiative and referendum elections. The most famous of these studies, which investigated voter support for five competing auto-insurance reforms, showed that citizens who knew insurance industry positions but lacked detailed factual knowledge about the measures voted similarly to citizens who possessed

140. This Subsection will focus on the problems voters face in discrete initiative and referendum elections. The indirect effects, however, of direct democracy on the utility of the party cue in representative elections also may be significant and adverse: the more law gets made outside of the legislative arena, the less it makes sense to blame the then-dominant party in the elected branches for outcomes one does not like. Direct democracy also gives interest groups more power over the agenda in

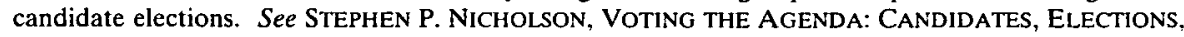
AND BALLot PROPOSITIONS 68-71 (2005).

141. Thad Kousser \& Mathew D. McCubbins, Social Choice, Crypto-Initiatives, and Policymaking by Direct Democracy, 78 S. CAL. L. REV. 949, 961-65 (2005).

142. Sean Bowler \& Todd Donovan. Demanding Cholces: Opinion, Voting, AND Direct DEMOCRACY 7-8 (1998).

143. See note 57 and accompanying text.

144. LUPIA \& MCCUBBINS, supra note 67, at 68-93; Arthur Lupia, Shortcuts Versus Encyclopedias: Information and Voting Behavior in California Insurance Reform Elections, 88 AM. POL. SCI. REV. $63,66(1994)$.

145. BOWLER \& DONOVAN, supra note 142 , at 55-66.

146. Id. at 64 . 
such factual knowledge. ${ }^{147}$ The third line of research looks at the correspondence between state policy as a whole and median voter preferences. An influential paper by John Matsusaka provided evidence that states with the ballot initiative come closer to the median voter's fiscal preferences than states without it. ${ }^{148}$

Further research has, however, cast considerable doubt on the revisionists' optimism. The question of whether policy is more or less congruent with public opinion in initiative states has become the subject of a running empirical debate. ${ }^{149}$ The most recent and methodologically sophisticated investigation found that initiative states performed no better than non-initiative states with respect to thirty-nine policies across eight issue areas. ${ }^{150}$

Other research questions ordinary voters' ability to make sensible choices based on simple cues in initiative elections. Voters may follow unreliable cues, ${ }^{151}$ and ignore probative cues. ${ }^{152}$ More basically, voters may be unaware of cue-givers' positions, or of the basis for trusting or discounting them.

As Thad Kousser and Mathew McCubbins argue, the costs of getting a measure on the ballot skew the direct-democracy agenda toward policies that would yield concentrated benefits for a narrow segment of the population and diffuse costs for everyone else. ${ }^{153}$ Such measures do not induce the well-organized, well-funded opposition campaigns needed to disseminate and explain cues that counsel against a "yes" vote. ${ }^{154}$ (Contrast healthy partisan elections, where the critical cues are provided on the ballot, linked to the governing coalition's performance, reasona-

147. Lupia, supra note 144 , at 63,72 .

148. John G. Matsusaka, Fiscal Effects of the Voter Initiative: Evidence from the Last 30 Years, 103 J. POL. ECON. 587 (1995).

149. See Jeffrey R. Lax \& Justin H. Phillips, The Democratic Deficit in the States, 56 AM. J. POL. SCl. 148,149 (2012).

150. Id. at 150 .

151. Cheryl Boudreau, for instance, has shown that experimental subjects will rely on unreliable opinion polls even when concurrently exposed to a cue-giver whom participants know to have the right answer and an incentive to reveal it. Cheryl Boudreau, The Market for Political Information: How the Consumption of Information Affects Citizens' Decisions 22-25 (Jan. 17, 2011) (unpublished manuscript), available at $\mathrm{http} / /$ papers.ssrn.com/sol3/papers.cfm?abstract_id=1742556.

152. Craig Burnett, Elizabeth Garrett, and Mathew McCubbins studied a ballot proposition about renewable energy and found no meaningful differences in voting patterns between voters who knew the details of the measure itself, voters who knew the electricity industry's position, and ignorant voters. Craig M. Burnett et al., The Dilemma of Direct Democracy, 9 EleCTION LAw J. 305 (2010); see also Craig M. Burnett, Informed Democracy? How Voter Knowledge of Initiatives Influences Consistent Voting (2010) (unpublished manuscript) (finding low levels of cue knowledge, and little evidence of such knowledge affecting vote choice, in other ballot-initiative election).

153. Kousser \& McCubbins, supra note 141, at 951-57.

154. To be sure, there is considerable evidence that public opinion does coalesce in a sensibly structured fashion during the course of well-funded campaigns over high-stakes ballot measures. This is evident from studies of term limits and redistricting reform, which show voters to be responsive to the positions taken by their parties. See Bowler \& Donovan, supra note 142, at 129-46; Caroline J. Tolbert et al., Strategic Voting and Legislative Redistricting Reform: District and Statewide Representational Winners and Losers, 62 POL. RES. Q. 92, 92 (2009). 
bly consistent over time, and endowed with meaning by campaigning on both sides.) The ballot initiatives most studied by academics address hotly contested subjects like Prohibition and term limits. ${ }^{155}$ But these elections, which featured robust campaigns and intense media coverage, are unrepresentative of the universe of ballot initiatives.

In ordinary proposition elections, most voters seem to rely heavily on the description of the measure on the ballot proper-and perhaps little else. ${ }^{156}$ If the description suggests that the measure will move policy in the direction the voter favors, she supports it; if not, she votes no. To the extent that vote choice in initiative and referendum elections depends on the measure's description on the ballot itself, we should be very worried indeed. The ballot description is often drafted by a less-than-impartial elected official. ${ }^{157}$ Misleading descriptions can have large effects on vote choice, even among voters who receive probative cues. ${ }^{158}$

The very complexity of ballot language can also foil the ordinary voter. A study of 1200 state-level ballot propositions found that the $a v-$ erage ballot question's complexity placed it beyond the reach of a mere college graduate, and unlikely to be fully understood by more than twenty-five percent of Americans. ${ }^{159}$

The bottom line is that a large swath of the electorate in typical initiative and referendum elections brings little policy or cue-based knowledge to bear on their choice. They glean what information they can from the ballot itself, and then take a stab at the question presented. ${ }^{160}$ Yet the ballot does little to help voters to learn whether a measure that "seems like a good idea," per its description on the ballot, actually is a good idea relative to the voter's values. 142.

155. See for example Bowler \& Donovan's widely cited book, DEMANDING CHOICEs, supra note

156. See, e.g., Burnett et al., supra note 152 (finding no meaningful differences in support for renewable energy measure across high-information voters, cue-knowing voters, and other voters; across all three groups, there was overwhelming support for the measure among voters who said they supported renewable energy even if electricity rates may rise, and overwhelming opposition among those who disagreed); Craig M. Burnett \& Vladimir Kogan, The Case of the Stolen Initiative: Were the Voters Framed? (September 10, 2010) (unpublished manuscript), available at http://papers.ssrn.com/ sol3/papers.cfm?abstract_id=1643448 (using survey experiments to demonstrate effect on public support of ballot-measure wording). Cf. BOWLER \& DONOVAN, supra note 142, at 55-59 (finding that self-interest had a much more powerful effect on respondents' position on a school voucher ballot initiative when respondents were provided with the proposition's ballot description and name, rather than the name alone).

157. For instance, the California Attorney General writes ballot titles and summaries for ballot initiatives. Richard J. Ellis, Signature Gathering in the Initiative Process: How Democratic Is It?, 64 MONT. L. REv. 35, 39-41 (2003).

158. Burnett \& Kogan, supra note 156.

159. Shauna Reilly \& Sean Richey, Ballot Question Readability and Roll-Off: The Impact of Language Complexity, 64 POL. RES. Q. 59, 61-62 (2009).

160. Many voters say that they also review the official ballot pamphlet, especially for evidence of elite endorsements, see BOWLER \& DONOVAN, supra note 142, at 55-59. But survey respondents likely exaggerate their use of this resource, just as they exaggerate voting. 


\section{B. Elections With Dysfunctional Party Brands: Mismatch and Michigan Problems in State and Local Elections}

Though nonpartisan elections have problems, the simple corrective of adding party labels to the ballot is not a miracle cure. This Section explains why the party-labeled ballot is often a less effective device for securing representative and accountable government at the state and local level than at the national level, for reasons that relate to-but go well beyond-voters' relative lack of attention to lower levels of government. ${ }^{161}$ Ironically, the party cue tends to be least reliable in lower profile elections, where voters are most likely to be lost at sea without it. (The principal alternative to electoral accountability at the subnational level-exit, or "voting with one's feet"-is a costly substitute. ${ }^{162}$ )

In federal systems like ours with first-past-the-post elections, there usually are two major parties, each of which wins a roughly equal share of the vote in national elections. ${ }^{163}$ The voters who favor each party in national elections, however, may be distributed very unevenly across the country. In a world of highly informed voters and flexible parties, the clustering of citizens by national party ID would not interfere with the normal workings of partisan competition with respect to state and local

161. This Section extends and supplements the theory of mismatch first presented in Schleicher, Why, supra note 2, at 447-65 and Schleicher, What If, supra note 2, at 139-48. Among other things, we provide new foundations in behavioral research on voting and partisanship, and new evidence concerning election and policy outcomes.

162. First, at the individual level, there are high transaction costs to picking up and moving in the face of bad governmental policies, particularly for people who have made substantial location-specific investments in their homes, workplaces, and social and professional networks. Second, when people choose where to locate based on local governmental policies, this distorts land markets and agglomeration economies, as it disturbs which individuals and businesses co-locate. See David Schleicher, The City as a Law and Economic Subject, 2010 U. ILL. L. REV. 1507, 1540-45. Finally, the substantial agglomeration economies (or strong preferences for locating near certain combinations of individuals and firms) we see in big cities also reduce the efficiency of sorting and exit as a producer of responsiveness and accountability in local government. Id. at 1535-40. As a result, exit produces a much weaker constraint on big city politics than it does on smaller local governments. See David Schleicher, I Would, but I Need the Eggs: Why Neither Exit Nor Voice Substantially Limits Big City Corruption, 42 LOY. U. CHI. L. REV. 277, 279-84 (2010). As such, improving local elections is important despite the ability of individuals to relocate. In a related vein, it has also been argued, most prominently by Paul Peterson, that the threat of exit by residents and businesses explains the lack of meaningful partisan competition in big city elections. The prospect of capital and resident flight is said to render local governments incapable of redistribution, and the types of issues that local governments commonly engage - what Peterson calls "developmental" and "allocational" policies-allegedly cannot give rise to partisan conflict. See PAUl PETERSON, CitY Limits (1981). City governments, however, do in fact enact redistributive policies; they are able to do so because of the stickiness of urban agglomerations. See Clayton P. GilletTe, Local Redistribution and Local Democracy: INTEREST Groups AND THE COURTS 50-70, 98-105 (2011). And partisan cleavages certainly can form around developmental and allocational issues, as is clear from national politics (e.g., environmental and education policy) and from the ideological competition we see in high-profile mayoral races over issues like policing, schools, and development. Schleicher, Why, supra note 2, at 430-37. In smaller places, local issues may be easier to understand than national ones but, in big cities, policy issues are effectively as complicated and distant from voters as national issues are.

163. This is a function of "Duverger's Law" and the median voter theorem. See Schleicher, Why, supra note 2, at 428-30. 
governments. If a state or municipality had a median voter to the right of the national median, for example, ordinary Downsian theory predicts that the national center-left party would develop a more conservative sub-brand specific to elections for local offices, tailored to the subnational government's median voter. About half of the voters, upon seeing that the formerly uncompetitive party now takes issues stances they prefer to its opponent, would support it. No level of government should suffer from uncompetitive elections for very long.

This, however, is just a theory. In fact, as we will show below, the party that wins national elections in a state or locality frequently dominates subnational elections in the same jurisdiction with little change in voting patterns based on local or state factors. Voters' preferences about President Obama, for instance, seem to be translated directly into their votes for dog catcher, or city council, or state senator; the actual performance of party-affiliated officials at the subnational level does not seem to matter.

Whether the enormous potential of partisan elections for securing responsive, accountable government is realized depends on three conditions, which state and local elections often do not satisfy. First, the ideological signal conveyed by the major-party brands - what the brands signify about the policy positions of party-labeled candidates - must be well calibrated to the issue-space and the electorate of the government in question. We will call a failure of this condition party-brand mismatch. Second, voters must see and respond to the jurisdiction-specific content of the brand, rather than understanding the brand purely or primarily in terms of events elsewhere. When voters instead understand local party brands primarily in terms of position-taking or performance by the party at another level, we will say that there is perceptual mismatch. Third, Michigan Voters in the jurisdiction - people whose partisanship is affective rather than informational - must affiliate with each party in roughly equal numbers. ${ }^{164}$ We will call a failure of this condition Michigan Voter imbalance. These problems are related, but for expositional clarity, we will treat them separately.

\section{The Problems Defined}

Before digging into evidence, let us first define the problems more precisely and explain how they are likely to interfere with representation and accountability in federal systems.

Party-Brand Mismatch. The potential of party labels to improve voter competence depends on their substantive calibration to the issuespace and electorate of the government to be elected. In a two-party sys-

164. Of course, one could say that party cues "function optimally" when there is no Michigan Vote at all. But affective partisanship is a reality, so the most one can realistically hope for is that the Michigan Vote will be self-neutralizing with respect to party control of the government. 
tem, party labels are well calibrated insofar as the issue positions embedded in each major-party label (1) differentiate the parties with respect to the issue-space; (2) track latent preference correlations across issues within the electorate, such that most policy-minded voters, given full information, would have no trouble saying which party's agenda they prefer; and (3) divide the electorate more or less evenly, such that the number of eligible voters who prefer one party's positions roughly equals the number who prefer the other party's positions. ${ }^{165}$ In subnational elections, these conditions seem frequently unmet.

A few examples will make these abstractions and their relevance for competent voting easier to grasp.

Imagine that half of the Democratic candidates running for city council favor and half oppose a community policing initiative; Republican candidates are similarly divided. On this issue, the party labels fail to differentiate the parties. To the extent that this occurs, the labeling of candidates with party brands will not enable voters to infer candidates' likely positions and to vote accordingly.

Now imagine that most voters who support community policing also favor a "look the other way" approach to nonviolent drug offenses. If the parties were to bifurcate on community policing and drug policy, but the Democrats favored community policing while the Republicans tolerated nonviolent drug offenses, we would have the second type of mismatched brand: differentiation would have occurred, but not in a manner that helps voters decide which party to support because the bundling of positions into party platforms goes against the grain of preference correlations within the electorate.

The third variety of party-brand mismatch would arise if one party took systematically extreme positions relative to the median voter in the electorate (for example, fiscal policy positions that appeal only to voters on the far left) and the other party positioned itself to appeal to all of the moderates. Here party labels would differentiate candidates cleanly but not usefully for the purpose of elections that properly determine the balance of power in government, i.e., legislative elections in districts whose median voter is ideologically similar to the median voter in the polity. If one party holds vastly more appeal for centrist voters than the other, the former party will have a lock on what should be "swing districts," and by extension on control of the government. The only elections that will matter are the dominant party's primaries, and as we have seen, primary elections are weak instruments of popular control. ${ }^{166}$

Perceptual Mismatch. For a low-information electorate to perform reasonably well, it is not enough that voters be provided with party-

165. This assumes a two-party system, rather than a multi-party regime with proportional representation.

166. See supra Part II.A.2. 
labeled ballots, and that the labels be ideologically calibrated to the issue-space and electorate for the government in question. Voters in the aggregate must also see and respond to the labels' government-specific content. If voters do not know what the party labels signify about candidate positions on local policy disputes, policy-minded voters will not be able to use the labels as shortcuts. Similarly, if voters cannot determine (or have biased perceptions about) whether local, state, or national officials are responsible for certain policies or conditions, voters' "running tally" evaluations of local (and national) party brands will be off.

Citizens who do not see the local content of major-party brands are likely to rely on their national party preferences when voting. This is rational when there is a positive (even if weak) correlation between local candidates' national party affiliation and local candidates' support for local policies the voter favors. ${ }^{167}$

Michigan Voter Imbalance. The existence of Michigan Votersaffective partisans whose voting decisions reflect their cultural ties to a political party rather than the parties' positions and performanceshould not much impede representation and accountability if the number of Michigan Voters affiliated with each party is roughly equal. Though individual seats may be essentially preassigned to one party or the other by a local predominance of affective Democrats or Republicans, the partisan balance of power in the legislative chamber will generally be determined by Bayesian updaters because Michigan types will cancel each other out. This may be a fair approximation of how national politics works.

But in subnational jurisdictions that are more Democratic or Republican than the nation as a whole, the locally dominant party by national ID will probably enjoy a "Michigan bonus." To illustrate, imagine an electorate divided 50:50 between pure Michigan Voters and pure Bayesians, and 60:40 between Democrats and Republicans. If there is an even distribution of Michigan types across parties, the Democrats will be guaranteed thirty percent of the vote in each election (to the Republicans' twenty percent), and the Republicans will need to win the "votes in play" - the votes of people responsive to information-by a landslide 60:40 margin in order to make the outcome a tossup. The Democrats, understanding this, will not be too concerned about losing medianBayesian-voter support. The Michigan Voter imbalance gives them a lot of slack.

167. Even for voters who do observe the doings of local party-affiliated officials, it is probably rational to put some weight on the doings of national officials when judging the local content of the party brand. The latter observations are not altogether irrelevant to the question of what local officials are likely to do with respect to issues found on both the local and the national policy agenda. But if party cues are ever to realize their potential as sources of prospective guidance and enablers of retrospective accountability in subnational jurisdictions whose median voter is unlike the national median, subnational electorates must be capable of seeing and responding to subnational party cues primarily in terms of the doings of party officials at the level of government in question. 
We will have more to say in a moment about the probable causes of party-brand mismatch, perceptual mismatch, and Michigan imbalances. But it will be helpful first to survey the evidence of how state and local government elections in fact perform. What evidence we have indicates that they perform poorly, in ways that are suggestive of each of these problems.

\section{Empirical Findings}

\section{a. Evidence from Municipal Elections}

If national political parties successfully rebranded vis-à-vis the issuespace and local electorate in municipal elections - and if voters correctly perceived the parties' local brands and voted accordingly-then one would expect to see robust partisan competition in municipal elections, with neither party enjoying long runs of dominance on city councils. There should also be consistent policy changes whenever control of the mayoralty switches from one party to the other. Yet in big city elections, as one of us has elsewhere noted, we observe nothing of the sort. ${ }^{168}$

Most big American cities support Democratic candidates for President by huge ratios, and vote shares in city council races closely track the presidential balloting. ${ }^{169}$ City councils have been dominated by one party not for the decade-long spans common in national and state legislatures, but for spans of a half-century or more. ${ }^{170}$ The only big-city councils subject to oscillating party control are found in cities whose electorates are pretty evenly divided in terms of national party identification. ${ }^{171}$

The election of more candidates of a given political party, which at the national level changes the direction of public policy, does not have similarly consistent effects at the local level. In a study of close mayoral races in Pennsylvania, Fernando Ferriera and Joseph Gyourko found no effect of Democratic (as opposed to Republican) control on the size of

168. Schleicher, Why, supra note 2, at 419-20.

169. Id. at 419-20, 424, 438 n.65. Existing research does not provide point estimates of the effect of party labels on vote choice in city council races, but a study of low-profile, multi-member school board races in Pennsylvania is suggestive. See Marc Meredith \& Jason A. Grissom, Partisanship in Local Elections: Regression Discontinuity Estimates from Unconventional School Board Races (Sept. 21, 2010) (unpublished manuscript), available at http://www.sas.upenn.edu/ marcmere/working papers/MeredithGrissomPartisanship.pdf.

Pennsylvania allows fusion candidates for school board. Using a regression discontinuity design to control for candidate quality, Meredith and Grissom find that winning a second party's endorsement is worth about fourteen to nineteen percentage points in vote share. Id. at 1 . That is, a candidate running as the nominee of both parties realizes a vote-share gain of about fourteen to nineteen percentage points, relative to the same candidate running as either the Democratic or the Republican nominee. When interpreting this result, bear in mind that adding a "Democratic" ("Republican") label to a candidate who already bears the other party's label sends a much weaker signal to Democratic (Republican) partisans than does adding a Democratic (Republican) label to an otherwise unlabeled candidate.

170. Schleicher, Why, supra note 2, at 438 n.65.

171. Id. 
local government, the allocation of local spending, or crime rates. ${ }^{172}$ Subsequent work on a national dataset of recent mayoral elections shows that the election of a Democrat leads to reduced spending on public safety but no other consistent effects. ${ }^{173}$ This is direct evidence that the parties do not have well-developed and differentiated local brands. ${ }^{174}$

In summary, local elections appear to suffer substantially from mismatch in party brands and in perceptions. The major-party brands contain little meaning specific to local governments. Voters, discerning little meaning, simply use their preferences about national politics when voting at the local level. ${ }^{175}$

\section{b. Evidence from State-Level Elections}

While local elections have all the indicia of mismatch, the evidence from state elections is a bit more complicated. Voting patterns and policy outputs speak to substantial mismatch in branding and/or perceptions. But new research suggests that state parties do try to rebrand themselves in the direction of the state's median voter. ${ }^{176}$ State electorates, however, seem fairly unresponsive to these rebranding efforts. Consider the following:

Within-State Competitiveness Across Levels of Government. If the major parties had well-tailored, state-level brands-and if state electorates discerned and responded to those brands - then there should be

172. Fernando Ferriera \& Joseph Gyourko, Do Political Parties Matter? Evidence from U.S. Cities, 124 Q. J. ECON. 349 (2009).

173. Elisabeth R. Gerber \& Daniel J. Hopkins, When Mayors Matter: Estimating the Impact of Mayoral Partisanship on City Policy, 55 AM. J. POL. SCI. 326 (2011).

174. To be sure, the evidence is also susceptible to other interpretations, for example, that local elected officials have control over public safety spending but little else in most cities. See id. at 327. Lest there be any confusion, it is not our view that the major-party brands are entirely uninformative with respect to city elections. Indeed, a weakly positive correlation between national party ID and local policy preferences is a necessary condition for the "party brand mismatch" story told below. Two forthcoming studies based on roll-call votes and candidate and voter questionnaires speak to this weakly positive correlation. One study examines recent roll call votes of the San Diego city council and shows that, in the rare instances where council members defect from the dominant, bipartisan governing coalition, Republicans generally defect to one side and Democrats to the other. San Diego is an unusual city because the electorate itself is about evenly split between Democrats and Republicans, giving the parties an exceptional incentive to develop locally meaningful brands. Craig M. Burnett \& Vladimir Kogan, Team Spirit: The Search for Party in Local Politics 19 (Nov. 1, 2010) (unpublished manuscript), available at http://papers.ssrn.com/sol3/papers.cfm?abstract_id=1701487. The other study uses issue-position questionnaires to create same-scale measures of candidate and voter ideology in the issue-space of San Francisco politics, and shows that the median Republican is somewhat to the right of the median Democrat (though there is lots of overlap between the parties in the local issue space, unlike in national politics). Cheryl Boudreau, Christopher S. Elmendorf, \& Scott A. MacKenzie, Lost in Space?: Shortcuts and Spatial Voting in Low-Information Elections (Paper presented at the 7th Annual Conference on Empirical Legal Studies, Stanford Law School, Nov. 9, 2012) (on file with authors).

175. Mayoral elections may be different than city council elections in this regard, because the office of mayor has a higher public profile and mayors may develop personal brands that differentiate them from their party. See infra Part III.A.2.a.

176. See infra notes $188-95$ and accompanying text. 
greater within-state partisan competitiveness, on average, in elections for state than for national office. To see this, imagine a very liberal state. Few congressional districts in this state will be competitive because the state's voters will overwhelmingly favor the national Democratic Party on ideological grounds. But if the state Republican Party developed a more liberal, state-level brand tailored to the state's issue space and electorate, and if voters responded to that brand, then Republicans should win (or be competitive in) roughly half of the state-level elections. Averaged across the nation as a whole, then, within-state competitiveness should be higher in state than in national elections. Yet the available data show precisely the opposite pattern: state legislative elections are less competitive than national elections in the state. ${ }^{177}$

Vote Swings in State and National Elections. If state-level party brands were well calibrated to state electorates - and heeded by voters in state elections - then one would not expect to see swings in the vote share of a given party in elections for state office closely track the voteshare of that party in elections for national office. To be sure, leftward or rightward shifts in the "public mood" ought to register similarly at the state and national levels, but other factors should tend to differentiate state and national election results. If Congress or the President moves too far to the right or left, enacts an unpopular law, or simply performs badly, state elections should be unaffected. ${ }^{178}$ Nor should national-level vote swings echo in the states when driven by issues for which the national government is principally responsible (such as foreign policy).

Yet as Figure 1 shows, ${ }^{179}$ seat losses by the President's party in Congress and in the lower house of state legislatures move in tandem. To the extent that mid-term congressional elections are a referendum on the President, the sentiments behind that referendum are just as forcefully manifested in state legislative races.

177. Robert D. Brown \& John M. Bruce, Political Parties in State and Nation: Party Advantage and Party Competition in a Federal Setting, 8 PARTY POL. 635 (2002) (finding substantially more competition in national than in state elections).

178. Here's another example. In national mid-term elections, there is evidence that the reason voters "swing" away from the President's party at the national level is that moderates seek to achieve centrist policy outcomes by strengthening the position of the other party in Congress. Joseph Bafumi et al., Balancing, Generic Polls and Midterm Congressional Elections, 72 J. POL. 705 (2010). This should not matter in state elections.

179. Thanks to Steve Rogers for providing the data. 
FIGURE 1

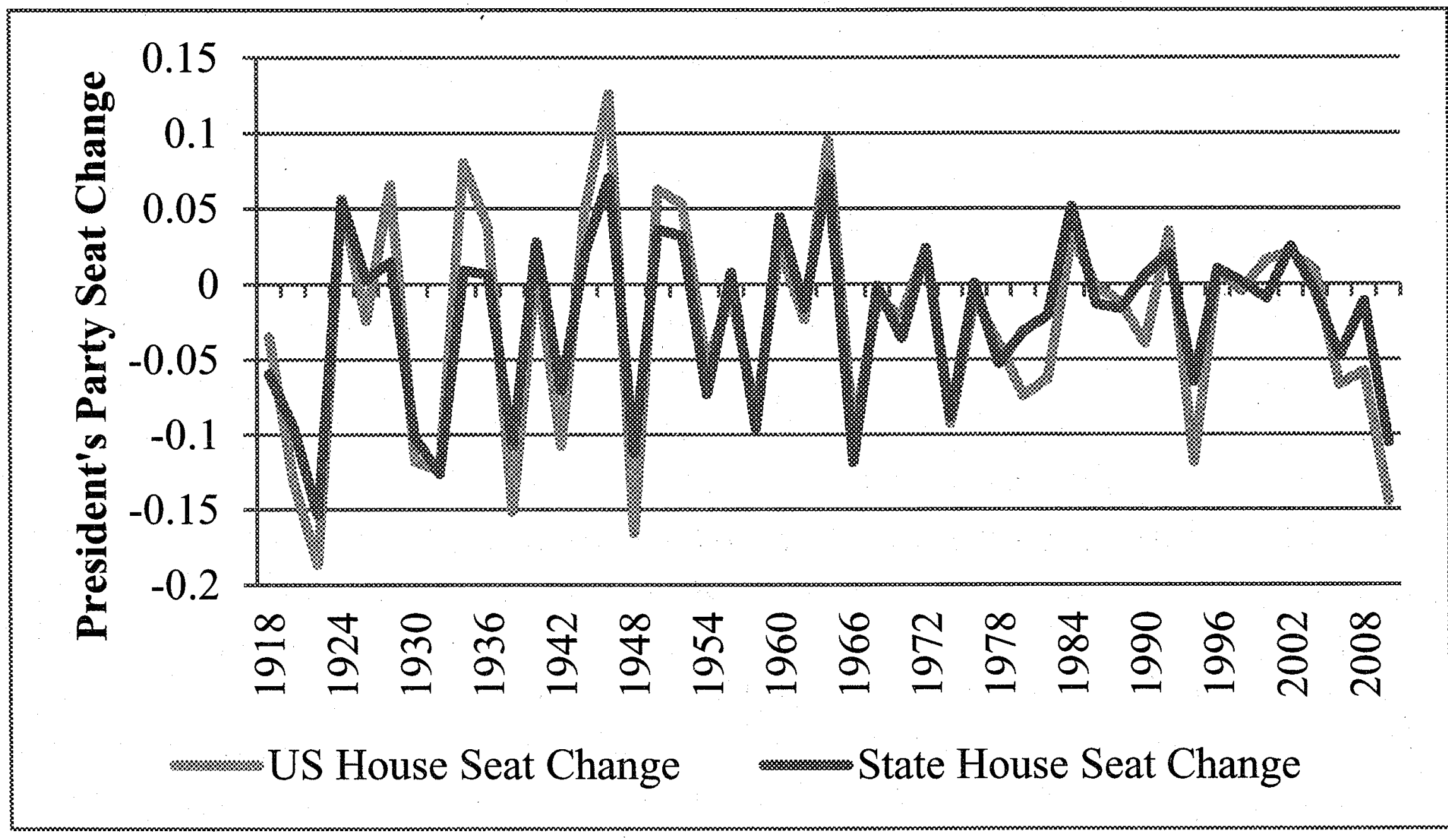

Using recent survey data, Steve Rogers has shown why state legislative elections so closely track national elections: the "driving force in [state] legislative elections" is approval of the President. ${ }^{180}$ European political scientists have a name for this phenomenon: the second-order election. ${ }^{181}$ A second-order election is one in which voters respond to candidates, and candidates appeal for votes, on the basis of political developments in a different arena. ${ }^{182}$ In some settings this is healthy. For example, it is a good thing for national political responsiveness that voters in mid-term congressional elections reward (punish) candidates of the President's party if they like (dislike) the President's performance. This is so because the issue-space over which each actor (the President and Congress) has influence is quite similar; and because the President's ability to implement his or her agenda depends on the relative strength of the President's party in Congress.

180. Steve Rogers, Collective Accountability in State Legislative Elections Obama: The State Legislator People Vote Against 13 (2012) (unpublished manuscript), available at http://www. princeton.edu/ rogerssm/www/dissertation.html. Controlling for the state of the economy and many other factors (including gubernatorial and state legislative approval), Rogers shows that a change from "strongly disapproving" to "strongly approving" of the President changes the predicted probability of voting for a candidate of the President's party in state legislative elections by at least forty percent. Id. Rogers corroborates the survey results with aggregate data going back to 1972, and shows that the President's party is punished in state legislative elections for poor economic performance. Id. at 1520.

181. The seminal paper is Karlheinz Reif \& Hermann Schmitt, Nine Second-Order National Elections - A Conceptual Framework for the Analysis of European Election Results, 8 EUR. J. POL. RES. 3 (1980).

182. Id. at 8-15 (developing hypotheses about characteristics of second-order elections); SIMON Hix, What's Wrong WiTh THE EUROPEAN UNION AND HOW TO FIX IT 80-84 (2008) (regarding European Parliament elections as second-order elections). 
But when party branding at a subnational (or supranational ${ }^{183}$ ) level of government with a distinctive issue-space and electorate is substantially determined by the party's national-level doings, partisan competition will not yield its usual benefits at the "secondary" level. Lawmakers whose hold on office at secondary levels is largely determined by their party's performance at the national level have little electoral incentive to govern effectively and in a manner responsive to the preferences of the subnational median voter. European political scientists have shown that both European Parliament and subnational elections in Europe are largely "second order," and Rogers's work demonstrates that this holds for U.S. state legislative elections are as well. ${ }^{184}$

Policy Congruence and Partisan Competition. A third source of doubt about the workings of major-party brands at the state level is Jeffrey Lax and Justin Phillips's cutting-edge study of the "congruence" (fit) between state policies and state public opinion. ${ }^{185}$ Across states, policies track popular opinion very weakly: "Roughly half the time, opinion majorities lose-even large supermajorities prevail less than $60 \%$ of the time. In other words, state governments are on average no more effective in translating opinion majorities into public policy than a simple coin flip." 186 Further, and contrary to expectations, Lax and Phillips found that one-party dominance does not diminish congruence; states with competitive elections are just as unresponsive to public opinion as oneparty states. ${ }^{187}$

Normally, greater competition should create pressure on incumbents to produce responsive policies. But this dynamic will not work at the state level if vote swings in state elections are artifacts of national politics, rather than being driven by the achievements and failings of the state's governing coalition. Lax and Phillips's results therefore corroborate the hypothesis that state voters do not see and respond to state party brands in terms of the parties' actual accomplishments at the state level.

There is, however, some evidence that state parties try to rebrand by fielding more liberal candidates in liberal states, and conservative candidates in conservative states. In the latest and best work on the subject, Boris Shor and Nolan McCarty used roll-call votes and surveys of

183. The theory of second-order elections was developed in response to election to European Parliament, in which national party preference determines almost all variation in elections to the supranational Parliament. See Schleicher, What If, supra note 2, at 119-30.

184. Rogers, supra note 180 , at 13-14.

185. Lax \& Phillips, supra note 149 , at 148.

186. Id. at 149 (reporting that one-party control bears on the direction of incongruence, but not the amount).

187. Id. Other research has found evidence consistent with the hypothesis that the imminent prospect of winning or losing control of state government induces lawmakers to invest in building statewide party brands. See Gerald Gamm \& Thad Kousser, Broad Bills or Particularistic Policy? Historical Patterns in American State Legislatures, 104 AM. POL. SCI. REV. 151 (2010) (finding, in a study of thirteen states over 120 years, that balance between "particularistic" (district oriented) and "general" (issue oriented) policymaking shifts toward the latter when parties are evenly balanced). 
candidates to map the ideological position of every state legislator, Member of Congress, and general election candidate into a single common space. ${ }^{188}$ Then, using survey-based estimates of voters' policy preferences, Shor mapped each state's median voter into the same common space, ${ }^{189}$ enabling a comparison of what politicians say (and how they vote) with what voters say they want.

This research reveals considerable state-by-state variation in the position of the median legislator in the Democratic and Republican state legislative caucuses, variation that is at least weakly correlated with public opinion. ${ }^{190}$ The median Democratic legislator in Mississippi, for example, is actually to the right of the median Republican legislator in New York, in keeping with the very conservative Mississippi electorate. ${ }^{191}$ Not all parties come near the median voter in their state, but some do.

The limited evidence on hand also suggests that some voters may see and respond to positioning and other activities by state legislative parties to some degree, though the effect on vote choice is modest. Bradford Bishop and Rebecca Hatch find that voting in state legislative elections is affected not only by such extraneous factors as presidential approval, but also by voters' perceptions of their relative ideological proximity to the state Democratic and Republican parties, and by their approval or disapproval of the state legislature. ${ }^{192}$ (Whether voters' perceptions of state-party positions correspond to reality is not answered by this work. ${ }^{193}$ ) Rogers also finds that state legislative approval affects vote choice in state legislative elections, although this effect is substantially attenuated by voter confusion about which party has majority control of the legislative body, and it pales in comparison to the effect of presidential approval. ${ }^{194}$

In a world where presidential approval and national party ID strongly influence vote choice in state elections, there are clearly limits to

188. Boris Shor \& Nolan McCarty, The Ideological Mapping of American Legislatures (Jan. 7, 2011) (unpublished manuscript), available at http://papers.ssrn.com/sol3/papers.cfm?abstract_id= 1676863. Shor and McCarty build on a classic: ROBERT S. ERIKSON ET AL., STATEHOUSE Democracy: Public Opinion and Policy in THE American STATEs 96-119 (1993). Note that these works assume that state and national politics have the same ideological structure, notwithstanding that some issues (like foreign policy) are part of one issue-space but not the other.

189. Shor, supra note 66.

190. Shor \& McCarty, supra note 188 , at 19 fig. 7.

191. Id.

192. Bradford H. Bishop \& Rebecca S. Hatch, Perceptions of State Parties and Voting in Subnational Elections 18-19 (2012) (unpublished manuscript), available at http://sites.duke.edu/ bradbishop/files/2012/11/sppq-7-4-12.pdf. In related work, they find that voters who perceive themselves as ideologically closer to different parties at different levels of government (e.g., Democrats at the state level, Republicans at the national level) are much more likely than other voters to split their ticket between levels of government. Bradford H. Bishop \& Rebecca S. Hatch, Ticket Splitting in a Complex Federal System 11 (2012) (unpublished manuscript), available at http://sites.duke.edu/ rebeccahatch/files/2012/09/Ticket-Splitting1.pdf.

193. Regarding the risk of mistaken perceptions, see infra Part II.B.3.b.

194. Rogers, supra note 180 , at 12 . 
what repositioning by a state legislative party can accomplish. Consider the case of Massachusetts. Shor finds that the state's median Republican legislator is extremely close to the median voter and that the median Democratic legislator is way out in left field - yet Republicans have been the minority party (and usually a very small one) in the Massachusetts legislature continuously since $1958 . .^{195}$

To sum up: there is some evidence of ideological recalibration by state parties to state electorates, but the stunning effect of presidential approval on vote choice in state legislative elections, the strong correlation between presidential party seat changes in Congress and in state legislative chambers, the surprising shortage of competitive elections at the state level, and the null effect of partisan competition on state-policy congruence, all suggest that rebranding is at best incomplete-and at worst largely irrelevant (as may result from mismatched perceptions and/or severe Michigan imbalances).

\section{The Mechanics of "Party Breakdown" in Subnational Democracies}

We have identified three phenomena that can explain the stylized facts of legislative elections at the state and local levels: mismatch in branding, mismatch in perceptions, and Michigan Voter imbalances. It remains to consider why these problems arise.

The first thing to observe is that the three problems are functionally interrelated. Mismatched perceptions and Michigan Voting (based on national party ID) in local elections would probably dissipate to some extent if the local wings of the national parties developed consistent, welltailored local brands. Eventually some citizens would see the local content of the party brands and start to vote accordingly. With the passage of time, even affective ties to party would probably be influenced by local branding.

Yet mismatched perceptions and Michigan imbalances are themselves impediments to rebranding. They reduce the electorate's responsiveness to the local content (if any) of the party brands, and the less responsive the electorate, the weaker the incentives for local party elites to undertake rebranding. Substantial investments in rebranding will only occur if local elites have very long time horizons, and believe that mismatched perceptions and Michigan imbalance would dissipate sufficiently in the long run to make the local minority party competitive.

For these reasons, it does not make sense to think of mismatched brands, mismatched perceptions, and Michigan imbalances as independent problems even though, as the balance of this Section will explain, certain forces may exacerbate or ameliorate each of the problems more or

195. Michael J. Dubin, Party AfFiliations in the STate Legislatures: A Year by Year SUMMARY, 1796-2006, at 94 (2007). 
less independently of the others. ${ }^{196}$

\section{a. Michigan Voter Imbalance}

Though the causes of Michigan-style party identification are not well understood, an imbalance of Michigan types seems likely whenever culturally and socio-economically similar voters congregate in the same cities, suburbs, and regions. Citizens do seem to cluster in this way, ${ }^{197}$ resulting in an overwhelming predominance of Democrats or Republicans (by national party ID) in some locales. There is some evidence that clustering is growing, ${ }^{198}$ and if some constant percentage of voters exhibit Michigan traits, this trend means that the problem of non-self-canceling Michigan Votes will make the general election pointless in an increasing number of state and local governments, irrespective of rebranding by the local minority party.

\section{b. Mismatched Perceptions}

Mismatch at the level of perceptions is also pretty easy to understand. It can result from voters' sheer obliviousness to subnational political events and governmental responsibilities, or from party-biased attribution of responsibility among levels of government when different parties control each level.

Voters in a federal system face competing demands for their political attention. If national politics dominates media coverage and the political conversation-as is likely owing to the higher stakes of national politics - the ideological meaning of party brands will probably be determined by what voters observe about the parties at the national level. ${ }^{199}$ For voters who are otherwise uninformed about subnational parties, it will be rational to rely on the national party labels in subnational elections so long as there is at least a weakly positive correlation between national party membership and subnational-policy preferences. ${ }^{200}$

Voters may also revert to their national party preferences in local

196. There are corresponding opportunities for policy interventions, the topic to which we will turn in Part III.

197. See BILl BISHOP, THE BIg SORT: Why THE CluSTERING OF LiKe-MINDED AMERICA IS TEARING US APART 2-16 (2008); Ian McDonald, Migration and Sorting in the American Electorate: Evidence From the 2006 Cooperative Congressional Election Study, 39 AM. POL. RES. 512 (2011); Clayton Nall, The Road to Division: Interstate Highways and Geographic Polarization (Nov. 14, 2011) (unpublished manuscript), available at http://www.nallresearch.com/uploads/7/9/1/7/7917910/roadto div.pdf. To be sure, there are some dimensions along which Americans are becoming less geographically clustered, such as race/ethnicity and family structure. See Charles R. Tittle \& Thomas Rotolo, Socio-Demographic Homogenizing Trends Within Fixed-Boundary Spatial Areas in the United States, 39 SOC. SCI. RES. 324, 337 (2010).

198. See Tittle \& Rotolo, supra note 197 , at 336.

199. This is an assumption, but one with substantial support in the literature. See Schleicher, Why, supra note 2 , at $454-56$.

200. Id. at 451 . 
elections because they lack the minimum information required for retrospective voting at subnational levels. To vote retrospectively in state and local elections, one must understand the partisan balance of power at different levels of government, and the distribution of public responsibilities across governments. One must also link changes in social and economic conditions to the responsible government. Voters have all sorts of trouble with these tasks. ${ }^{201}$

Further, the mistakes they make often run together in the aggregate owing to partisan bias in perceptions. As Adam Brown has shown, when the President and the Governor belong to different parties, voters rate the relative performance of the state and national economies in line with their partisan predispositions. ${ }^{202}$ That is, underlying "policy outcomes" are perceived differently, depending on respondents' partisanship. Partisanship also biases attributions of responsibility: good outcomes (in fact or perception) are attributed to the level of government controlled by the voter's party, whereas bad outcomes are blamed on the level of government controlled by the other party. ${ }^{203}$

The bottom line is that, owing to inattentiveness and/or biased perceptions, voter perceptions of local and state party brands may have little to do with the actual performance of officials and candidates at the corresponding level of government.

\section{c. Party-Brand Mismatch and Barriers to Rebranding}

When one party dominates a subnational government because of residents' national political preferences, one might expect the local branch of the national party that regularly loses elections to rebrand itself vis-à-vis the local median voter. ${ }^{204}$ But political entrepreneurs who

201. See supra notes $86-93$ and accompanying text. This is true at a level of government as well as between levels - if voters blame Members of the House for actions taken by the Federal Reserve, for example, accountability withers. See Fred Cutler, Whodunnit? Voters and Responsibility in Canadian Federalism, 41 CAN. J. POL. SCI. 627, 650-51 (2008) (finding that with Canadian data, when compared to the opinions of political scientists, ordinary citizens make systematic errors in attributing responsibility to different branches of government); Bryan Caplan et al., Systematically Biased Beliefs About Political Influence: Evidence from the Perceptions of Political Influence on Policy Outcomes Survey (2011) (unpublished manuscript) (on file with authors) (finding that, when compared to the opinions of political scientists, ordinary citizens make systematic errors in attributing responsibility to different branches of government); Rogers, supra note 180, at 9,12 (estimating that two-thirds of CCES respondents were uncertain about party control of the state legislature, and that mistakes diminished the impact of state legislative approval on vote choice in legislative elections by roughly fifty percent).

202. Adam R. Brown, Are Governors Responsible for the State Economy? Partisanship, Blame, and Divided Federalism, 72 J. POL. 605 (2010).

203. Id. For a review of the literature on party-biased perceptions and retrospective voting, see Christopher J. Anderson, The End of Economic Voting? Contingency Dilemmas and the Limits of Democratic Accountability, 10 ANN. REV. POL. SCI. 271, 278-81 (2007); see also Geoffrey Evans \& Mark Pickup, Reversing the Causal Arrow: The Political Conditioning of Economic Perceptions in the 2000-2004 U.S. Presidential Election Cycle, 72 J. PoL. 1236 (2010).

204. One might also expect third-party entry, but there are almost no successful third parties in local government elections in American cities. See Schleicher, Why, supra note 2, at 447 . This is likely 
would carry out this rebranding confront a suite of challenges. Some of these arise from legal regulations of the electoral process; ${ }^{205}$ others are the result of regular facts about voter and candidate behavior that occur whenever parties of the same name contest elections at different levels.

In the United States, as one of us has elsewhere argued, election law unnecessarily unifies parties across levels of government. ${ }^{206}$ Most significantly, voter registration laws do not permit citizens to belong to different parties at different levels of government. ${ }^{207}$ A New York City resident who is "center left" on the national political spectrum and "right" on the city's political spectrum cannot register as a national Democrat and a municipal Republican.

Unified registration rules make it hard for the local minority party to field a competitive slate of candidates in municipal elections, since the party's primary electorate is likely to be comprised entirely of voters on a distant fringe of the municipality's ideological spectrum. ${ }^{208}$ Unified registration rules also impede efforts to develop clear, differentiated party brands on local issues that are orthogonal to or weakly correlated with the main dimension of national politics. ${ }^{209}$ For example, if half of the Democrats and half of the Republicans in the New York City primary electorate support community policing and the rest oppose it, the parties are unlikely to develop clearly differentiated positions on this subject, notwithstanding the strong divide within the electorate. If voters could separately enroll in local and national parties, it would be easier for community policing advocates to throw their weight to one of the parties and for party leaders to recruit new registrants on this basis, reshaping the primary electorate in the process.

due to many of the same forces that hinder major-party rebranding, discussed in this Section.

205. Here we touch briefly on certain election laws that may operate as barriers to rebranding. We leave for another day an investigation of how the structural constitution (e.g., separated powers, supermajority decision rules, the ballot initiative, term limits, redistricting) and legislative compensation may bear on party elites' incentive to develop competitive state and local sub-brands.

206. This argument draws on Schleicher, Why, supra note 2, at 450-51 (introducing the concept of "Unitary Party Rules").

207. Here's another example: in many states, parties earn automatic ballot access for down-ballot races-including races for city offices-through a strong showing in the gubernatorial race. Id. at 450 \& n.108. Automatic ballot qualification makes it likely that the "number two" party in local elections will be the locally disfavored national party, rather than a new entrant that lacks the baggage of the locally disfavored national party. Once the locally disfavored national party is on the ballot at the local level, it becomes harder for new entrants to attract voters and candidates.

208. Notably, this assumes that voters develop partisan identification on the basis of national, and not local, issues, an assumption for which there is substantial evidence. Schleicher, Why, supra note 2, at 454-57. It also assumes that the primary election outcomes are at least somewhat responsive to the ideological makeup of the primary electorate, which is more doubtful. See supra Part II.A.2. This second assumption, however, need only be weakly true for the argument to work. For primary and registration laws to be a cause of mismatch, it only has to be the case that the absence of agreement among party members on local issues negatively affects the party's ability to field candidates with consistent, popular stances on local issues.

209. There are reasons to believe that most local government issues work this way. See Schleicher, Why, supra note 2, at 437-44. 
In theory, states and cities could respond to the difficulty of rebranding by banning national parties from fielding candidates, leaving the field to local-only parties. But here the First Amendment stands in the way. State efforts to ban political party endorsements in nonpartisan and primary elections have been invalidated on First Amendment grounds, ${ }^{210}$ and it's likely that a state law excluding national parties from local partisan elections would face substantial constitutional challenges. ${ }^{211}$

On top of these hard barriers to rebranding, there are a number of softer barriers resulting from voter psychology, residential choice, and candidate incentives, rather than state interventions in the political marketplace, which likely prove equally important in retarding localized rebranding.

First, political entrepreneurs who undertake rebranding must sell their subnational party brand to an electorate whose attention is generally elsewhere. In the few subnational races with substantial media coverage and higher stakes, the development of local brands may be possible. Mayoral and gubernatorial candidates from the local minority party are sometimes successful because they garner enough attention to develop and sell their own brand. ${ }^{212}$ But for down-ballot candidates or for a local party as a whole, voter inattention raises the cost of rebranding substantially. So too do Michigan-Voter imbalances. A minority-party entrepreneur who sees a huge mass of inert voters on the other side will understand that a rebranding campaign might not be worth the effort.

Even if the electorate is not inert, the minority-party entrepreneurs face a credible-commitment problem. They must convince voters that what they say is what they will $d o$ if put in power. ${ }^{213}$ Talk is cheap; so too is voting if you are a legislator whose party is perpetually in the minority. If a party has been so long out of power that even the most attentive voters have no subnational "running tally" to draw upon in judging it, and if the subnational median voter's running-tally assessment of the party at the national level is decidedly negative, it will be no easy task to convince the subnational electorate to give the minority party a chance to prove itself at the reins of state or local government.

Supply-side factors-specifically, the desire of local candidates or activists to move up through a vertically integrated party to higher, more powerful levels of government-may also thwart rebranding. Consider a

210. Eu v. S.F. Cnty. Democratic Cent. Comm., 489 U.S. 214, 216 (1989); Cal. Democratic Party v. Lungren, 919 F. Supp. 1397, 1398-99 (N.D. Cal. 1996).

211. See Schleicher, Why, supra note 2, at 468-72 (analyzing the constitutionality of such proposals).

212. See infra Part III.A.2.a.

213. Recall Shor's perplexing discovery that Republican state legislators in Massachusetts are much closer to the state's median voter than their Democratic counterparts. See Shor, supra note 189, at 19 fig.6. It may be that the Republicans' failure to convert their ideological proximity into majority status owes to many voters' disbelief that Republican lawmakers would continue to vote this way if given control of the statehouse. 
city outside of the national political mainstream, like San Francisco. Imagine that a local group of moderate Republicans tries to create a distinctive "San Francisco Republican" brand, and does careful polling to identify wedge issues that could split municipal Democrats, such as publicsector pensions, school reform, and aggressive panhandling. But to have any traction with the median voter in San Francisco, the Republicans discover that they would also have to stake out positions that are anathema to the national party, like supporting same-sex marriage and city-funded abortion clinics. If they have any ambitions to go further in politics, these San Francisco Republicans would face a dilemma. Becoming competitive locally would ruin their careers in state and national politics, and diminish their access to state and national networks of party funders. The smart play may be to avoid getting involved in local politics at all. ${ }^{214}$

Finally, it bears emphasis that rebranding entrepreneurs do not write on clean slates. The major party brands already have welldeveloped meanings, established through national politics. Rebranding the Republican Party for San Francisco is like rebranding the local McDonald's as a purveyor of haute cuisine.

\section{Summary}

Commentators have long sung the virtues of government "closer to the people." But empirical research on state and local elections casts doubt on this position. Many subnational elections appear to be plagued by mismatch between the ideological content of the major-party brands and the issue-space and electorate of the subnational government; and/or by mismatch between voters' perceptions of the party brands and the parties' actual positions and achievements in the subnational government. These problems can be compounded by disparities in the number of Michigan Voters affiliated with each party in the jurisdiction.

\section{IMPLICATIONS}

Ever since The American Voter, the question for political scientists studying voter ignorance has been "whether democracy works" given how little voters know about politics. The main lesson of Part II was that that question has no single answer-democracy is likely to work less well in some places and better in others, holding constant the level of voter knowledge. We turn now to the question of what this implies for the field of election law, beginning with policy and then moving to constitu-

214. The extent to which such strategic considerations retard rebranding is probably context dependent. It depends on how pervasive and strong the desire to "move up" is within the pool of potentially strong local candidates (and how big that pool is). And it depends on whether national-level actors and primary voters in a jurisdiction are willing to tolerate local efforts to develop "deviant," competitive sub-brands, or whether they are too worried that such brands will muddy voters' apprehension of what the national party stands for. 
tional law.

We argue that policymakers concerned with voter competence face a threshold, fork-in-the-road choice: whether to provide partisan information on the ballot, while adopting other reforms meant to foster voter understanding of party brands and major-party rebranding to the issuespace and electorate in question, or whether to suppress partisan information on the ballot and provide what we will call party substitute cues instead. At present, the choice between these strategies is largely a matter of guesswork, because so little is understood about either the dynamics of party rebranding or the efficacy of party substitutes. We will offer a number of hypotheses and reform suggestions meant to inform subsequent research and institutional tinkering.

Our analysis of the voter information problem also has implications for the courts. We argue that the Supreme Court has badly flubbed the "state interest" side of the balance in its party-rights cases. More tentatively, we also propose a new way to think about rights of association with political parties. Our proposal would resolve a number of longstanding conundrums in this body of law.

\section{A. Better Voting: On Parties and Party Substitutes}

Legal-academic commentary on the problem of informed voting has been focused almost entirely on campaign-finance disclosure regimes. ${ }^{215}$ Relying on the "cues" literature, a number of scholars have argued that a central objective of campaign finance law should be to reveal, promptly, the "real party in interest" behind large donations to candidates, issueadvocacy campaigns, and ballot measure committees. ${ }^{216}$ Once this information enters the public domain, the argument goes, opposition figures and the news media will bring it to the attention of voters for whom it is useful. ${ }^{217}$ Some advocate even stronger measures. Michael Kang and Justin Levitt, for instance, have argued that source information should be disclosed to voters as part of the political communication itself, with state-mandated voiceovers and labels. ${ }^{218}$

Elizabeth Garrett, the election law scholar most attuned to the information problem, has also recognized that the ballot itself represents a

215. For some exceptions, see sources cited supra note 2.

216. See, e.g., Elizabeth Garrett \& Daniel A. Smith, Veiled Political Actors and Campaign Disclosure Laws in Direct Democracy, 4 ElECTION L.J. 295 (2005); Richard L. Hasen, The Surprisingly Complex Case for Disclosure of Contributions and Expenditures Funding Sham Issue Advocacy, 48 UCLA L. Rev. 265 (2000); Michael S. Kang, Democratizing Direct Democracy: Restoring Voter Competence Through Heuristic Cues and "Disclosure Plus," 50 UCLA L. REV. 1141, 1176-83 (2003). But see Lloyd Hitoshi Mayer, Disclosures About Disclosure, 44 IND. L. REv. 255, 257-71 (2010) (critiquing disclosure advocates for presupposing an attentive, engaged electorate).

217. Garrett \& Smith, supra note 216 , at 297.

218. Kang, supra note 216 , at 1176-83 (regarding voiceovers); Justin Levitt, Confronting the Impact of Citizens United, 29 YALE L. \& POL'Y REV. 217, 225-29 (2010) (proposing "Democracy Facts" label). 
uniquely promising medium through which to educate low-information voters. ${ }^{219}$ Information provided on the ballot is available at low cost to voters, and accessible precisely when it's needed. (As discussed in Part II, there is compelling evidence that party labels on the ballot substantially affect vote choice, as does the language used to describe ballot measures.) Garrett has suggested that candidates be allowed to make short statements on the ballot, with which candidates could identify their key endorsers as well as dubious sources of support for their opponents. ${ }^{220}$ Garrett has also proposed that a public agency be given authority to identify issues of top priority to the electorate, to poll candidates for their positions on those issues, and to print the candidates' responses on the ballot. ${ }^{221}$

We are intrigued by Garrett's ballot-improvement project, and quite sympathetic to the goal of revealing the identity of major donors. But the legal-academic commentary has missed something important: the singular virtues (for informed voting) of well-calibrated party cues, and of transparent, low-cost information about party control of government.

For reasons that should be clear by now, a well-calibrated partisan cue, provided on the ballot for easy consumption by ordinary voters, likely has far more potential to improve voter performance than does disclosure of big-money interest-group and corporate donors. For the disclosure model to pay dividends, the election campaign must be high profile so that ordinary voters are actually aware of the interest-group cues. Further, the electorate must be pretty sophisticated, consisting of voters who can successfully link interest-group cues to their own interests or ideological beliefs, and who are not bamboozled by warring cues. ${ }^{222}$

The disclosure model would have more of an upside, as Garrett has recognized, if it were feasible to provide interest-group cues on the ballot itself. But here great danger lurks. As James Gardner points out, statements on the ballot amount to unrebutted arguments with the potential to similarly affect large numbers of poorly informed voters. ${ }^{223}$ What would otherwise have been self-canceling errors in voter beliefs can become correlated errors as a result, reducing the aggregate competence of the voting public. Even if voters are not misled, ballots filled with candidate statements and interest-group cues would be considerably longer, and longer ballots result in more "rolloff"-abstention from down-ballot

219. Garrett \& Smith, supra note 216 , at 296.

220. Garrett, supra note 2, at 1584-86.

221. Id. at $1582-86$.

222. The political scientist Cheryl Boudreau recently began an important research project on the comparative operation of party and interest-group cues. Her initial laboratory experiments show that party cues are much more powerful than endorsements by party-affiliated interest groups. Cheryl Boudreau, Conflicting Cues, Consistent Opinions? How Party Cues and Endorsements Affect Public Opinion (2011) (unpublished manuscript) (on file with authors).

223. James A. Gardner, Neutralizing the Incompetent Voter: $A$ Comment on Cook v. Gralike, 1 ELECTION L.J. 49, 59 (2002). 
races - reducing the representativeness of the electorate in those races. ${ }^{224}$

Well-calibrated partisan cues are uniquely suited to inclusion on the ballot itself. They are succinct, encapsulating within a single word or phrase a host of issue positions. They matter to all ideological voters because they separate the leading candidates on the main divisions of politics. (By contrast, an interest-group cue is germane only to particular issues, which generally matter only to narrow issue-oriented publics.) And partisan cues are useful even to non-ideological voters-so long as the voter has an opinion about the government's performance-because partisan cues, unlike interest group cues, enable voters to relate candidates to the incumbent governing coalition. Finally, the meaning of party cues cannot easily be shaded by the manner of their presentation on the ballot. They are just labels after all, not exercises in political rhetoric.

So the question arises, what can law do to improve party labels, especially in light of party-brand failures? And, further, is there anything that law can do when well calibrated party labels are not enough - when attribution errors, or non-self-canceling Michigan Votes, or a simple lack of knowledge about which party was in control deprives the party label of its ordinary utility as an aid to collective choice and accountability? We think there is.

But reformers must make a threshold choice between two mutually incompatible strategies. We shall call these the better partisan voting strategy, and the party substitutes strategy. The former entails clarifying linkages between the government, the major parties, and candidates for office; lowering the cost to voters of acquiring this information; and structuring the legal regulation of political parties so as to enable and encourage rebranding to the issue-space and electorate associated with the government in question. The party-substitutes strategy suppresses the very same information - raising the cost to voters of learning about party-candidate and party-government linkages-while inducing the creation of alternative, party-like cues and furnishing these on the ballot.

There are significant tradeoffs between these strategies, which we cannot fully explore given space limitations. Party-substitute cues can be more precisely tailored to the subnational government in question, and they offer more leverage against Michigan-Voter imbalances and partybiased perceptions. But because party-substitute cues would vary by name from one jurisdiction to the next, voters would face higher search costs than if the conventional party labels were used everywhere (and correlated in their content across jurisdictions). Potential economies of scale in branding would also be lost.

224. See Peter Selb, Supersized Votes: Ballot Length, Uncertainty and Choice in Direct Legislation Elections, 135 PUB. CHOICE 319, 319, 325 (2008) (finding that longer initiative ballots result in greater roll-off, more confusion and a reduction in "voters' ability to translate their political preferences into consistent policy choices"). 


\section{Better Partisan Voting (Through Law)}

Reformers who opt for the better partisan voting strategy may pursue it on a number of levels. They may undertake to improve the availability of major-party cues, voters' apprehension of the cues, the consistency of the cues, and the tailoring of the cues to issue-space and electorate in question. The balance of this Subsection presents a number of reform suggestions, but we offer them more as ideas worth exploring and testing rather than as confident prescriptions.

\section{a. Availability}

Partisan cues are available to the extent that voters know the cue at the moment of decision. The most obvious availability-oriented reform is to convert formally nonpartisan representative elections into formally partisan elections, with candidates nominated by political parties and labeled accordingly on the ballot. Availability strategies may also prove fruitful in other presently unlabeled elections, such as initiative and referendum elections, and primary elections. These elections could be given partisan form by authorizing party organizations ${ }^{225}$ or party caucuses in the legislature to make ballot-printed endorsements. ${ }^{226}$

\section{b. Apprehension}

A party label has been apprehended to the extent (1) that voters correctly infer what the party label signifies about candidate issue positions with respect to the government in question (ideological apprehension), and (2) that voters understand the partisan balance of power in the government (retrospective apprehension). ${ }^{227}$ Small election law changes (as well as big constitutional changes) could improve apprehension along

225. In the case of primary elections, it might also be useful to empower minor parties to make ballot-printed endorsements in the primaries of either or both major parties. Knowing which candidates have been endorsed by significant minor parties could help primary voters to differentiate candidates for the party's nomination. (A Christian Coalition Republican is likely to govern quite differently than a Libertarian Republican.) Giving minor parties this role might also help to bring disaffected factions into the two-party system, which should improve voter performance as third-party candidates result in more incorrect voting. See Lau et al., supra note 102, at 407.

226. Seema Mehta, State GOP Tries to Craft Its Own Mail-In Primary Before Prop 14. Takes Effect, L.A. TiMES, Mar. 28, 2011, http://articles.latimes.com/2011/mar/28/local/la-me-adv-gop-prop1420110326. Similarly, county party organizations are sometimes allowed to "bracket" candidates together to create slates. See Andrews v. Rajoppi, A-4005-0771, 2008 WL 1869869 (N.S. Super. App. Div. Apr. 29, 2008).

227. It should be noted that clarity or distinctness between parties is a different thing from ideological distance between the parties, although both make voting decisions easier. Parties can be completely distinct-i.e., all Democrats being to the left of all Republicans-and quite close together on an ideological scale. In fact, distinctness might increase competition for the median voter, as party members and leadership do not have to take far-left or right votes to make clear to their base that they are really Democrats or Republicans and not DINOs or RINOS. See James M. Snyder, Jr. \& Michael M. Ting, An Informational Rationale for Political Parties, 46 AM. J. POL. SCI. 90, 90 (2002) (developing a model that suggests that clarity of party labels increases centrism). 
both dimensions, thereby diminishing the problem of mismatched perceptions.

Retrospective Apprehension. We suspect that one minor reform to ballot design would dramatically improve retrospective apprehension, especially among less attentive voters. Ballots should "label" the existing partisan balance in government, not just the endorsement of candidates by political parties. A large fraction of the electorate does not know the existing partisan balance even in national elections. ${ }^{228}$ Designating party control on the ballot itself would enable many more citizens to hit the right target when voting retrospectively. As noted earlier, recent work by Steve Rogers suggests that if all voters knew which party controlled their state's legislature, the effect of voter approval (or disapproval) of the state legislature on support for candidates of the majority party would roughly double..$^{229}$

Another, more far-reaching technique for facilitating retrospective apprehension is to consolidate offices and functions at a given level of government. Political scientists have shown repeatedly that retrospective voting is sensitive to the clarity of control. ${ }^{230}$ Multi-party governments and separated powers undermine retrospective accountability; singleparty control enables it. Seen in this light, the existing separation-ofpowers pattern in the United States is strange. As one moves down the governmental hierarchy (from national, to state, to local), one typically finds more rather than less separation of powers and functions. Thus, many states have plural executives, with separately elected governors, attorneys general, comptrollers, and the like, in addition to bicameral legislatures. ${ }^{231}$ At the local level, one finds not only separately elected city councils, mayors, prosecutors, and city attorneys, but also a division of power and functions between the general purpose municipal or county government, the school board, and any number of "special districts" with narrowly defined responsibilities. ${ }^{232}$

For purposes of democratic accountability, this makes little sense..$^{233}$ The less informed the electorate about a given level of government, the more important it is to limit the electorate's monitoring responsibilities and to simplify its choices.

Ideological Apprehension. Any reform that improves retrospective apprehension will also enhance ideological apprehension. Voters who

228. See supra note 86.

229. See supra note 201.

230. See Anderson, supra note 203, at 281-86.

231. On the costs of plural executives, see Daniel B. Rodriguez, State Constitutional Failure, 2011 U. ILL. L. REV. 1243, 1273-79.

232. See generally RICHARD BRIFFAULT \& LAURIE REYNOLDS, CASES AND MATERIALS ON STATE AND LOCAL GOVERNMENT LAW 8-16 (7th ed. 2009).

233. It also makes little sense in terms of the conventional diffusion-of-power rationale for separated powers. Lower-level governments have fewer powers than higher-level governments, and abuses may be checked by corrective action taken at a higher level. 
know which party is responsible for policies recently in the news will also have a better sense of what that party stands for ideologically.

There are also, we think, unexplored opportunities for improving ideological apprehension via direct democracy. The inclusion of a line below each ballot initiative that told voters which political parties supported it would help voters who know something about the initiative to learn something about the party, as well as voters who know something about the party to learn something about the initiative.

Ideological apprehension might also be advanced by introducing a modified, party-based version of the referendum. Suppose that each major-party caucus in the legislature were authorized to put one referendum measure on the ballot during each legislative election. These would likely be seen by voters as representing the party caucuses' preeminent legislative objectives, ${ }^{234}$ and as such would convey more information about party ideology than would the caucus's decision to endorse (with a ballot label) a quotidian ballot initiative. The party referendum measures would probably receive lots of campaign attention, both because of their signification about what the party stands for, and because the caucuses and the candidates they support would invest in spreading the message. ${ }^{235}$ We suspect that the "party-caucus referendum" would be particularly helpful in jurisdictions that have long been dominated by one party, where voters trying to gauge the likely policy consequences of voting the opposition party into power have no reservoir of experience with its rule to draw upon. ${ }^{236}$

\section{c. Consistency}

Party cues are consistent insofar as candidates running under the party label espouse the same positions and stick to them over time. Consistent cues are easier for voters to use, but there is a tradeoff to be struck because too much consistency would impede party adaptation and eventually result in uncompetitive elections. Reformers should ask whether the person or entity who ascribes the party label-primary voters, caucus goers, etc. - is well placed to make the tradeoff. We do not have particularly ingenious ideas for how best to strike the balance, but we are skeptical of regimes such as Washington state's "top two" prima-

234. At least with respect to the minority party, which is blocked from achieving its objectives through the ordinary legislative process.

235. Contrast the abstract and lengthy platforms that party activists draw up. These do not become law when the party is voted into power, and, having been drafted by activists rather than legislators, they may not well reflect the views of the figures who really count, i.e., government officials elected on the party label.

236. Note that improving voters' understanding of the principal opposition party should also facilitate retrospective voting against the party in power. See Anderson, supra note 203, at 284-85 (reviewing studies showing that retrospective voting is contingent on voters "perceiv[ing] viable alternatives"). 
ry, which permits candidates to self-ascribe party labels. ${ }^{237}$

\section{d. Tailoring (Undoing Party-Brand Mismatch)}

The most difficult and delicate task for reformers pursuing the better partisan voting strategy is figuring out how to induce the development of differentiated, well-tailored party sub-brands that are legible to voters at the state and, especially, the local government levels. The difficulty of this task owes to the variety of forces that can cause party-brand and perceptual mismatch; to the intractability of some of those forces (such as voter inattention to lower-stakes governments); to the lack of empirical research on the dynamics of rebranding; and to the U.S. Supreme Court's jurisprudence of political party rights. ${ }^{238}$

But one should not infer that the project of better tailoring through law is hopeless. One positive step, mentioned earlier, is to permit voters to register as members of different parties for purposes of different levels of government. ${ }^{239}$ Comparatively conservative Democrats in liberal states and cities would be free to participate in state and local Republican primaries without abandoning the Democratic primary for national office; vice-versa for relatively liberal Republicans in conservative states and cities. This should help the local minority party to become more competitive vis-à-vis the median voter in the locale. ${ }^{240}$ (While this reform would face a substantial constitutional challenge, other reforms that enable party switching on Election Day, such as "same-day registration," could also help and would likely be on safer ground. ${ }^{241}$ )

Local party activists and officials will not, of course, be motivated to build a competitive local brand unless citizens are willing and able to vote in state and local elections on the basis of local rather than national party preferences. The main barriers here are cognitive and affective, though strategic voting could be a factor too if lower-level governments can shape the partisan balance of power at higher levels. ${ }^{242}$

237. Cf. Mathew Manweller, The Very Partisan Nonpartisan Top-Two Primary: Understanding What Voters Don't Understand, 10 ELECTION L.J. 255 (2011) (documenting extensive voter confusion about the signification of party labels under Washington's system).

238. See infra Part III.B.

239. Similarly, laws giving automatic ballot places in local elections to parties that do well statewide could be repealed. See Schleicher, Why, supra note 2, at 468-70.

240. To be sure, one-party dominance might still be hard to dislodge, for strategic voters may be reluctant to leave the one primary that matters in any given election. However, shocks to the political system, like a scandal followed by a particularly attractive candidate opting into the opposing primary, could shake the party system at the local level into some kind of competitive balance.

241. Rebranding might also be encouraged by structural reforms that increase the payoff to winning (subnational) median-voter support, and that lengthen the time horizon of legislators serving in subnational government. In the first category are things like eliminating supermajority requirements for the passage of legislation, and crafting legislative districts so as to create a large "winner's bonus" for whichever party draws the most votes. In the second category are things like eliminating term limits and increasing legislative pay.

242. The most significant current tie between state-level elections and party control over the fed- 
Ballot designers may be able to soften affective barriers to voting against one's national party preference by describing party brands in terms of the government at issue. If this reform were implemented, San Francisco voters (for example) would receive a ballot labeling candidates for national office "National Democrat" or "National Republican," candidates for state-level office "California Democrat" or "California Republican," and candidates for municipal office "San Francisco Democrat" or "San Francisco Republican."243 The geographic signifier would remind San Francisco liberals that "Republican" might not have the same meaning at different levels of government.

Electoral reforms that loosen party-enrollment requirements for participating in primary elections may also tend to soften affective ties between voters and parties. In an ingenious field experiment, Alan Gerber and colleagues showed that "independent leaners" in Connecticut who were reminded that they had to enroll with a party to vote in the upcoming presidential primary not only enrolled and voted at higher rates than members of the control group, they also displayed more characteristically partisan evaluations of the President and Congress than independent leaners in the control group. ${ }^{244}$ Other research has shown that voters self-identify as independent at higher rates in states with closed than open primaries, ${ }^{245}$ and that party identification appears to be stickier in the closed-primary states. ${ }^{246}$

More generally, anything that gives voters access to low-cost, reliable information about governmental performance should help to solve the mismatch problem. ${ }^{247}$ Better information about subnational government performance will reduce mismatch at the level of perceptions, and thereby incentivize minority-party activists to rebrand their party so that it represents an ideologically plausible alternative for the subnational median voter who is dissatisfied with the incumbent regime's perfor-

eral government is state legislatures' control over congressional redistricting. The adoption of independent redistricting for congressional elections might, on the margins, increase citizens' willingness vote in state elections on the basis of state rather than national considerations.

243. This example presumes that municipal officeholders compete in partisan elections. In California as in many other states, local government elections are presently nonpartisan. See CAL. CONST. art. $2, \S 6$ (a) (requiring all local elections to be nonpartisan).

244. Alan S. Gerber et al., Party Affiliation, Partisanship, and Political Beliefs: A Field Experiment, 104 AM. POL. SCI. REV. 720 (2010) (explaining that an independent leaner is a voter who selfidentifies as independent but reports being "closer" to one party than the other).

245. See, e.g., Barry C. Burden \& Steven Greene, Party Attachments and State Election Laws, 53 POL. RES. Q. 63 (2000); Anna Harvey \& Bumba Mukherjee, Electoral Institutions and the Evolution of Partisan Conventions, 1880-1940, 34 AM. POL. RES. 368 (2006). Though Burden and Greene use cross-sectional data, they find that the effect occurs only among citizens who are registered to vote, suggesting that it is causal.

246. Matthew P. Thornburg, Party Registration and Party Identification: How Institutional Rules Affect the Stability of Party Identification (2012) (Paper presented at the 2012 Conference of the Midwest Political Science Association) (on file with authors).

247. Consider for example Heather Gerken's promising proposal for a "Democracy Index," designed to inform voters in Secretary of State elections about the relative quality of their state's election administration system. GERKEN, supra note 2, at 15-26. 
mance.

\section{Substitutes for the National Party Labels}

The previous Subsection provided a grab bag of ideas for improving the quality of party labels. But what can be done for states and cities where the quality of major-party labels is essentially irrelevant (as may result from an imbalance of Michigan Voters), where mismatch proves incurable, or where entrenched legal norms require nonpartisan elections? The simplest remedy is to permit home-grown parties to contest local elections while excluding the national parties. ${ }^{248}$ But this would face a substantial First Amendment challenge. ${ }^{249}$

Alternatively, the subnational government could adopt formally nonpartisan elections - candidates would qualify for the ballot by gathering signatures or paying filing fees - while providing voters with party label substitutes on the ballot. A party-label substitute, as we use the term, is an alternative notation that functions like a well-calibrated major-party cue, in that it (1) locates candidates along the main ideological dimension of politics at the level of government in question, (2) is binary in character, (3) divides the electorate pretty evenly along the main ideological dimension, (4) develops meaning as voters observe politics and link conditions in the world around them to the figures then in charge of government, and (5) resists manipulation through the manner of its presentation on the ballot. ${ }^{250}$

What alternatives to conventional party labels would function in this way? In the balance of this Subsection, we sketch a couple of proposals, one modest and the other more ambitious. The modest option is to authorize the most powerful elected official in the jurisdiction (e.g., the mayor or governor) to make ballot-printed endorsements in legislative races. The more ambitious alternative is to establish a novel system of advisory primaries, which would be open to voters and candidates without regard to party affiliation and would incentivize participants to sort into competing umbrella coalitions on the basis of their local policy preferences.

248. See Schleicher, Why, supra note 2, at 470-73. Cf. Schleicher, What If, supra note 2, at 117-18, 152-56 (proposing a supranational vote distribution requirement to induce the formation of new, supranational parties for purposes of European Parliament elections-elections that are presently contested and won in each member state by national parties competing on the basis of domestic rather than EU issues).

249. See Schleicher, Why, supra note 2, at 468-73.

250. As explained above, the interest-group cues that many legal commentators and some political scientists see as critical to competent, low-information voting do not have these properties. See supra notes $141-57$ and accompanying text. 


\section{a. The Executive Cue $\mathrm{C}^{251}$}

Voters are better informed in mayoral and gubernatorial elections than in other local and state elections. ${ }^{252}$ These executive officials receive much more media coverage than their counterparts in state and local legislatures, ${ }^{253}$ and candidates and interest groups spend much more money on gubernatorial and mayoral races than on races for the state and local legislatures.

The information differential is evidenced by the fact that out-party candidates for mayor and governor in one-party-dominated states and cities occasionally win, notwithstanding the failure of their co-partisans' efforts to gain control of the legislative chamber. As recently as 2010, Brad Henry, a Democrat, was the governor of inveterately Republican Oklahoma; Giuliani and Bloomberg, running as Republicans, won the mayoralty in deep-blue New York City.

Mayors and governors are also distinctive because of the electoral pressures they face. They are elected at large, so they must appeal to the median voter in the jurisdiction as a whole-much more so than local legislators, whose district-level constituencies may not resemble the jurisdiction as a whole, and who are elected in lower turnout contests. ${ }^{254}$ But mayors and governors are not slaves to the median voter; they must also answer to the coalition of interest groups and foot soldiers that backed their campaigns. As a result of these cross-cutting pressuresand relatively high levels of media coverage and public attentionmayors and governors may become "brand names" that resemble, in their ideological content, a major-party brand within a healthy two-party system.

Our proposal is simple: Give the Mayor or Governor the power to make on-ballot endorsements. This "executive cue" would position voters to leverage their opinions, positive or negative, about the most widely

251. The argument of this Subsection was first sketched in Chris Elmendorf \& David Schleicher, Making Democracy Work in San Francisco, S.F. CHRONICLE, Feb. 28, 2010, at E4.

252. Recent experimental and survey research by David Anderson shows that voters focus on presidential and gubernatorial races at the expense of concurrent congressional races, and that voter search in each race is strongly correlated with correct placement of the candidate on a seven-point ideology scale. David J. Anderson, Pushing the Limits of Democracy: Concurrent Elections and Cognitive Limitations of Voters (May 2011) (unpublished Ph.D. dissertation, Rutgers University), available at $\mathrm{http}: / \mathrm{mss} 3$. libraries.rutgers.edu/dlr/showfed.php?pid=rutgers-lib:33379. Anderson did not investigate voter search in concurrent state legislative races, but it is unlikely that voters pay more attention to concurrent state legislative races than to concurrent congressional races.

253. See, e.g., Scott L. Althaus \& Todd C. Trautman, The Impact of Television Market Size on Voter Turnout in American Elections, 36 AM. POL. RES. 824, 829-31 (2008) (citing studies and explaining economic incentives for local television stations to focus on statewide elections rather than districted legislative races, especially in large media markets).

254. Cf. Zoltan L. Hajnal, America's Uneven Democracy: Race, Turnout, and REPRESENTATION IN CITY POLITICS 88-90, 151-52 (2010) (noting that cities with council-manager governments, where the city council appoints a nonpartisan manager, have lower turnout than cities with mayoral elections). 
recognized official with a locale-specific platform in elections where they are relatively poorly informed. And, like a party cue, the executive cue would enable voters to empower or check the political coalition at the helm of government by voting for or against that coalition's candidates in legislative races. ${ }^{255}$

To be sure, the executive cue is an imperfect substitute for true, well-calibrated party cues. The cue would prove harder for voters to use than true party brands, because the trademark would change every time a new person obtains the executive's office. The utility of the executive cue is also limited by its one-sidedness. Endorsement of a candidate for legislative office by the mayor or governor implies that the candidate would support the endorser's agenda, but the executive cue doesn't inform voters about which of the other candidates is the best agent of the primary opposition coalition. Unlike a true party cue, the executive cue would not solve the opposition's coordination problem in pluralitywinner elections. Finally, unpopular executives might strategically withhold the executive cue, or assign it disingenuously to an uncompetitive candidate so as not to hurt a stronger ally.

All that said, if the major party cues are persistently dysfunctional in a city or state, formally nonpartisan elections coupled with ballotprinted mayoral (gubernatorial) endorsements may enable a lowinformation electorate to achieve better results than would conventional partisan elections. ${ }^{256}$

\section{b. Advisory Primaries}

We think it is possible to improve on the executive cue by inducing the creation of de facto local political parties and labeling candidates accordingly on the ballot. The regime we envision would be designed to mimic a genuinely local two-party system, while standing a better chance of surviving constitutional challenge than a regime of ordinary partisan

255. Existing research on whether voters' opinions about the governor affect support for his or her copartisans in partisan state legislative races finds mixed results; the effect is no doubt limited because conventional party cues trigger so many other powerful associations, such as opinions about the President and national party identification. Using CCES data, Rogers, supra note 180, at 13, finds a significant effect of gubernatorial approval-albeit less than half the magnitude of the effect of presidential approval-controlling for economic conditions and approval of the state legislature. By contrast, Bishop and Hatch, who add controls for the perceived ideological position of state parties (but do not control for economic conditions) find no effect of gubernatorial approval. See Bishop \& Hatch, supra note 192, at 16-17. Earlier work employing more limited data sets also finds mixed results; see, e.g., Michael A. Bailey \& Elliott B. Fullmer, Balancing in the U.S. States, 1978-2009, 11 STATE POL. \& POL'Y Q. 148 (2011); Olle Folke \& James M. Snyder, Jr., Gubernatorial Midterm Slumps, 56 AM. J. POL. SCl. 931 (2012); Mike Mayo, The Relationship Between an Incumbent Governor's Popularity and State Legislative Election Outcomes: A Contemporary Assessment of the Coattails Phenomenon (Jun. 17, 2004) (unpublished masters thesis, Virginia Polytechnic Institute), available at http://scholar.lib.vt.edu/theses/available/etd-06182004-141837/unrestricted/PSCI5994.pdf.

256. The executive cue might also be used to good effect in other subnational elections for which state law mandates a nonpartisan ballot, such as initiative and referendum elections. 
elections from which successful national parties have been banned. Here's how we would organize it:

- Candidates would qualify for the general-election ballot through a conventional nonpartisan process, such as gathering signatures or paying a filing fee.

- Any self-selected group of citizens (of a certain size) could petition to sponsor a state-organized, state-administered advisory primary, setting forth in their petition a name for the primary and a statement of principles meant to attract candidates and voters to the event. Signers of the petition need not be members of any organization or have any prior legal identity, except as individuals.

- Petitioners, in naming the primary, could not use the names of ballot-qualified political parties that field candidates in partisan elections.

- The advisory primaries would be open by law to candidates and voters without regard to party affiliation. But candidates and voters would be permitted to enter only one such primary per election cycle for the level of government in question.

- The winners of the two advisory primaries that achieved the highest levels of voter participation would be designated on the general election ballot as the winners of their respective advisory primaries. The ballot would not designate the winners of other advisory primaries, or of any nomination process that a political party might carry out on its own.

- The winner of the most popular advisory primary (by number of voters participating) would appear first on the ballot; the winner of the next most popular primary would appear second; and the remaining candidates would appear in random or alphabetical order.

- Public funding, if any, would be distributed to advisory primary winners in proportion to the number of voters participating in each primary.

This regime would create powerful incentives for interest groups, candidates, and voters to band together into a pair of competing umbrella coalitions, akin to the major parties in a well-functioning two-party system. Aiming for the perks of "top two" status-ballot label, ballot position, and money-advisory-primary organizers would craft initial platforms that are attractive to large swaths of the electorate. Candidates hoping to benefit from a ballot label will participate only in what look to be the two most popular of the advisory primaries, lest the candidate end up the "winner" of an advisory primary that does not yield a ballot label. Similarly, engaged voters will opt into the two most popular 
of the advisory primaries because that is where they will find the strongest candidates, and where they will avoid wasting their vote in a primary that does not yield a ballot notation.

This regime would also provide strategic advisory primary voters with very good reasons not to "raid" the main alternative primary to the one they prefer (in the hopes of making an unattractive candidate the winner). Raiding under the system we propose would operate to transfer tangible benefits-money and ballot position-from the winner of the voter's preferred advisory primary to his or her principal opponent. These deterrents to raiding should help to stabilize the meaning of the ballot labels.

The provisions that deter raiding will simultaneously incentivize elites to mobilize broad primary turnout. This should help to educate the masses about what each coalition stands for, and to further stabilize the meaning of the labels. (The more voters who participate, the harder it is for a highly mobilized fringe of the electorate to determine the winner.)

In short, this regime should result in a fully functional de facto twoparty system, in which the advisory primary brands are well calibrated to the issue-space and electorate for the government in question. Elected officials will customarily have affiliated with one or the other of the dominant advisory primary coalitions, enabling citizens to link government performance to the "team" in charge, and to vote accordingly in the next election. And the leading advisory primary brands would be reused in successive elections, giving them some of the consistency of real party brands. ${ }^{257}$

Indeed, our advisory primary regime might well outperform the conventional party system with primary elections in some respects, even apart from mismatch or failures due to an imbalance of Michigan Voters. By linking public financing and ballot position to primary-election turnout, our model creates stronger incentives for elites to mobilize broad participation and does away with the need for restrictive advanceregistration rules (conventionally defended as antidotes to raiding). ${ }^{258}$ It is a fair hope too that voters would have weaker affective ties to "their" advisory primary than to their political party, with a corresponding reduction in cognitive bias and Michigan-style voting. ${ }^{259}$ Voters would not

257. The consistency, both across time and across offices at a level of government, and the tailoring of the advisory-primary labels are what set our regime apart from California's "top two" nonpartisan primaries with self-labeling of candidates.

258. In conventional primaries, each candidate has incentives to mobilize only his own supporters-while discouraging turnout by the other candidates' supporters. The party as a whole has no interest in boosting primary turnout.

259. Our advisory primary system is also likely to outperform its nearest real-world counterpart: "fusion" systems, under which several parties can nominate the same candidate, allowing candidates to have more bespoke brands. See Schleicher, Why, supra note 2, at 469 . Fusion is now allowed only in New York, where it has helped mayoral candidates like Rudy Giuiliani and Michael Bloomberg distance themselves from their national parties. Id. Fusion differs from our proposal in critical respects, 
need to register or enroll in an advisory primary group to cast a primary ballot, nor would the groups that request advisory primaries necessarily have any legal life between elections. ${ }^{260}$

Would the advisory primary regime survive a constitutional challenge? We cannot be sure-no one has a very good record predicting Supreme Court decisions in party rights cases-but we think it would. For reasons we have made clear, states and cities have a very strong interest in providing voting cues that will not be read through the lens of national politics. And, in contrast to a system of formally partisan elections from which the national parties have been excluded, our regime does not discriminate against any subgroup of recognized political parties. ${ }^{261}$ The parties would be free to nominate candidates however they wish, subject to the proviso that their nominees will not be designated as such on the ballot, just as they can under the familiar, long-established protocols for formally nonpartisan elections.

To be sure, our advisory primary regime would discriminate against political parties as a class, in that they alone-relative to the larger class of organized associations - could not be featured in the name of an advisory primary label. But this naming restriction is minor, and could be justified as a truth-in-advertising measure. ${ }^{262}$ Because the advisory primary must be open to all voters without regard to their party registration, the organizers' decision to name an advisory primary after an already recognized political party would be deceptive, as it would falsely imply that candidates bearing the advisory primary ballot label were endorsed by a political party. ${ }^{263}$ Save for the fact that they may not give their collective name to an advisory primary ballot label, political party members who want to organize an advisory primary would stand in exactly the same position as members of any other assemblage of citizens. ${ }^{264}$

however, in that it leaves the major parties on the ballot (we would exclude all de jure parties), and encourages the formation of numerous minor parties (we aim for just two advisory primary brands). The proliferation of minor parties under fusion taxes a low-information electorate. Tellingly, fusion has not enabled Republican candidates to seriously challenge the Democratic dominance of New York City Council, notwithstanding the contemporaneous success of Giuliani and Bloomberg. Id.

260. Regarding the effects of party-registration requirements on party identification, see supra notes $244-46$ and accompanying text.

261. The Supreme Court has applied generally deferential review to formally nondiscriminatory restrictions on political-party participation in the electoral process. See, e.g., Timmons v. Twin Cities Area New Party, 520 U.S. 351, 358 (1997).

262. Minor burdens on political organization and expression created by election law receive exceedingly deferential review. See generally Christopher S. Elmendorf, Structuring Judicial Review of Electoral Mechanics: Explanations and Opportunities, 156 U. PA. L. REV. 313, 335-38 (2007).

263. Some courts have recognized a very strong state interest in avoiding voter confusion about the meaning of ballot labels. See, e.g., Dart v. Brown, 717 F.2d 1491, 1510 (5th Cir. 1983).

264. The naming restriction could also be justified as an exclusion from a nonpublic forum - the space on the ballot reserved for advisory primary labels - of a class of putative "speakers" whose message content falls outside the purpose of the forum. Courts faced with constitutional challenges to restrictions on what may be said in state-published voter guides, or on the ballot itself, generally treat these venues as nonpublic or limited-public fora in which the state has free hand to limit the topics (content) that may be addressed, and, related to this, the speakers who may do the addressing, so long 
Petitioners for an advisory primary might also challenge the openness requirement on associational grounds, but here too they would probably fail. Unlike an ordinary primary, an advisory primary would not have the effect of deciding the endorsement of any existing private or quasi-private group. ${ }^{265}$ No existing organization would be deprived of anything, relative to the constitutionally permissible baseline of a conventional nonpartisan election. ${ }^{266}$ The citizens who petition for an advisory primary would have more in common with the people who sign papers to get an initiative on the ballot than with members of an organized group bearing conventional rights of association. ${ }^{267}$ These citizens, operating under ground rules specified in advance, would not have a protected interest in the labeling of candidates apart from the interest of voters who affiliate by participating in the organizers' primary.

But whatever holes, constitutional or otherwise, exist in our proposal should not be taken as fatal. The advisory primary concept can be modified in any of a number of ways. Don't like the selective exclusion of political parties from lending their name to advisory primary labels? Expand the ban to include all existing organizations. Think that's a problem? Have the government create two generically named advisory primaries-Yellow and Purple-that people can sort into. There will be no private advisory primary organizers to assert First Amendment claims and the Yellow and Purple labels will eventually develop political identities through repeated practice (although with less certainty and less quickly than under our proposal). Object to the top-two limitation in the labeling rules? Get rid of it. A two-label regime will likely evolve anyway, for the ordinary Duvergian reasons, ${ }^{268}$ although again with less cer-

as the state remains neutral as to viewpoints with respect to the content of the forum. See, e.g., Cogswell v. City of Seattle, 347 F.3d 809, 814 (9th Cir. 2003) (classifying voter guide as a limited public forum); Schrader v. Blackwell, 241 F.3d 783 (6th Cir. 2001) (treating ballot labels as a nonpublic forum). The state's purpose in setting up the forum, as it were, is to communicate to voters where candidates stand on local issues. Naming an advisory primary after a national party would introduce information inappropriate for the forum.

265. See Wash. State Grange v. Wash. State Republican Party, 552 U.S. 442, 454 (2008) (rejecting party organization's facial challenge to rule allowing candidates to list their party preference on the ballot in a formally nonpartisan "top two" primary because it did not determine the endorsement of a party nor were voters likely to be confused that it did).

266. To be sure, an advisory primary organizer could conceivably misappropriate an existing organization's brand. In that case, the organization might have a cause of action for trademark infringement, but not a constitutional basis for objecting to the state law.

267. Organizers of ballot petition drives do have protected "associational" interests in the actual process of gathering signatures. See, e.g., Buckley v. Am. Constitution Law Found., Inc., 525 U.S. 182 (1999) (Thomas J., concurring); McLaughlin v. N.C. Bd. of Elections, 65 F.3d 1215, 1221 (4th Cir. 1995). First Amendment associational interests would not, however, be implicated by restrictions on what may be achieved, as a matter of law, through the ballot petition process. $C f$. Gordon v. Lance, 403 U.S. 1 (1971) (upholding supermajority vote requirements for the enactment of certain referendum measures). A challenge brought by petitioners for an advisory primary to the ground rules for the primary itself would fall into the latter category.

268. Assuming first-past-the-post elections, Duverger's Law holds that the political system will tend toward having two major parties. MAurice Duverger, Political Parties: Their ORGANIZATION AND ACTIVITY IN THE MODERN STATE (Barbara North \& Robert North trans., 1959). 
tainty and less quickly than under our proposal.

Perhaps advisory primaries are not the answer. But something like them-a party-like substitute - would be enormously useful in jurisdictions where the Michigan Vote is not neutralized through aggregation, where the major parties cannot be induced to develop well-tailored local brands, and where voter perceptions of the local content of the majorparty brands are swamped or distorted by the voter's take on the parties as national-level actors. ${ }^{269}$

\section{B. The Constitutional Law of Party Rights}

Our account of the voter information problem has implications not only for policymakers, but also for judges faced with constitutional challenges to the regulation of political parties. The Supreme Court treats the First Amendment as a source of protections for the autonomy of political parties, and for parties' access to the ballot in formally partisan elections. The Court has held, for example, that the state may not bar a political party from inviting unaffiliated voters to participate in its primary; ${ }^{270}$ or require parties to nominate candidates through "blanket primaries" open to nonmembers; ${ }^{271}$ or impose on party organizations a particular corporate form, or an obligation not to endorse primary-election candidates. ${ }^{272}$

Prevailing doctrine subjects "severe" burdens on political parties' First Amendment interests to strict scrutiny, whereas reasonable, nondiscriminatory restrictions (sometimes called lesser burdens) receive very lax review. ${ }^{273}$ To implement this framework, courts must be able to evaluate the strength of state interests brought forth on behalf of challenged regulations, and have some principled basis on which to distinguish severe from lesser regulatory burdens. Our analysis of the voterinformation problem casts serious doubt on much that the Supreme Court has said when evaluating state interests. It also points toward a potentially useful way of thinking about burden severity.

\section{State Interests in the Regulation of Political Parties}

States have often defended public regulation of political parties and the candidate-nomination process by arguing that the First Amendment

269. We do not mean to imply that "party substitutes" are the only way to attack the voter information problem when party cues are absent or unavailing. As the introduction to Part III noted, many other questions about the effects of law on voter competence are worth investigating.

270. Tashjian v. Republican Party of Conn., 479 U.S. 208, 229 (1986).

271. Cal. Democratic Party v. Jones, 530 U.S. 567, 578 (2000).

272. Eu v. S.F. Cnty. Democratic Cent. Comm., 489 U.S. 214, 229 (1989).

273. See generally Christopher S. Elmendorf \& Edward B. Foley, Gatekeeping vs. Balancing in the Constitutional Law of Elections: Methodological Uncertainty on the High Court, 17 WM. \& MARY BILL RTS. J. 507 (2008). 
burdens of the election law at issue are outweighed by the law's benefits for voter competence or, one step removed, for the "integrity" of the major parties. The Supreme Court's responses to these arguments run the gamut from equivocal and naïve to ludicrous and possibly disastrous.

Three problems concern us particularly. One, the Court has been evasive about whether the promotion of informed voting is a "compelling" state interest, and as such potentially capable of sustaining a law subject to strict scrutiny. For years the Court danced around this issue, ${ }^{274}$ nowadays, it tends to describe the interest as "important," placing it in the netherworld between "legitimate" and "compelling."27s

The second problem lies in the Court's default empirical suppositions about what voters know and how they behave. On more than one occasion the Court has answered arguments about the importance of consistent party labels by declaring "[the defendant's] argument depends upon the belief that voters can be "misled" by party labels. But our cases reflect a greater faith in the ability of individual voters to inform themselves about campaign issues."276

On the basis of this faith the Justices cavalierly dismissed both the state's defense of mandatory closed primaries in Tashjian v. Republican Party of Connecticut, ${ }^{277}$ and the major parties' attack on Washington's "top two" primary regime with candidate self-ascription of party labels. ${ }^{278}$ A similar faith in the diligence and attentiveness of the voting public underwrote the Court's rejection of early filing deadlines for independent candidates in Anderson v. Celebrezze, ${ }^{279}$ and durational residency requirements for voting in Dunn v. Blumstein. ${ }^{280}$ "Faith" is the key word

274. See, e.g., Kramer v. Union Free Sch. Dist. No. 15, 395 U.S. 621, 631-33 (1969) (avoiding question of whether the state may "in some circumstances ... limit the exercise of the franchise to those 'primarily interested' or 'primarily affected'" in response to voter ignorance); Dunn v. Blumstein, 405 U.S. 330, 356-57 (1972) ("[W]ithout deciding as a general matter the extent to which a State can bar less knowledgeable or intelligent citizens from the franchise, we conclude that durational residence requirements cannot be justified on this basis." (internal citations omitted)).

275. The "important" formulation traces to Jenness v. Fortson. 403 U.S. 431, 442 (1971) ("There is surely an important state interest in requiring some preliminary showing of a significant modicum of support before printing the name of a ... candidate on the ballot - the interest ... in avoiding confusion, deception, and even frustration of the democratic process at the general election." (emphasis added)).

276. Tashjian v. Republican Party of Conn., 479 U.S. 208, 220 (1986) (internal quotation marks and citations omitted).

277. Id.

278. Wash. State Grange v. Wash. State Republican Party, 552 U.S. 442, 454 (2008) ("[R]espondents' assertion that voters will misinterpret the party-preference designation ... depends upon the belief that voters can be 'misled' by party labels. But our cases reflect a greater faith in the ability of individual voters to inform themselves about campaign issues." (internal citations and quotation marks omitted))

279. 460 U.S. 780,797 (1983) ("[T]oday the vast majority of the electorate not only is literate but is informed on a day-to-day basis about events and issues that affect election choices and about the ever-changing popularity of individual candidates.").

280. 405 U.S. 330,358 (1972) ("[T]he State cannot seriously maintain that it is 'necessary' to reside for a year in the State and three months in the county in order to be knowledgeable about... elections." (internal citations omitted)). 
here. The Court has shown little interest in what political scientists actually understand about voting. ${ }^{281}$ It has simply presumed a "well informed electorate," 282 one in which "the vast majority" of voters follow "on a day-to-day basis [the] events and issues that affect election choices."283

This may explain the third and most glaring flaw in the political rights jurisprudence: the Court's repeated suggestion that the most promising means for improving voter competence-the adoption of regulations meant to strengthen political parties and better calibrate their cues - is not even a legitimate object of state action.

In Tashiian, for example, the Court shockingly concluded that the "relative merits of closed and open primaries" for "promot[ing] responsiveness by elected officials and strengthen[ing] the effectiveness of the political parties" are flat-out irrelevant to whether the state may require major political parties to close their primaries to nonmembers. ${ }^{284}$ Similarly, in California Democratic Party v. Jones, the Court pronounced that states may not regulate partisan primaries with the goal of "producing elected officials who better represent the electorate."285 This, the Court said, was "simply circumlocution for producing nominees and nominee positions other than those the parties would choose if left to their own devices" and as such "a stark repudiation of freedom of political association." ${ }^{286}$ And in Eu v. San Francisco County Democratic Central Committee, the Court held that states may not regulate the structure and governance of party organizations, or prevent party organizations from making endorsements in primary elections, because "even if a ban on endorsements saves a political party from pursuing self-destructive acts, that would not justify a State substituting its judgment for that of the party."287

Whatever one makes of the asserted First Amendment interests on the other side of the balance, the Court's position that there can be no legitimate state interest in regulating the major parties' internal organization or candidate nomination procedures for the purpose of maintaining reliable party cues and better representing the electorate is indefensible. In our two-party system, these are the major parties' principal social

281. A partial exception is Dunn v. Blumstein, where the Court did point to evidence suggesting that most learning about candidates occurs during a brief period before the election. See id. at 358 n.30 (citing studies).

282. Wash. State Grange, 552 U.S. at 454.

283. Anderson, 460 U.S. at 797. As one would expect, the Supreme Court's error has ramified through the lower courts. See, e.g., Wash. State Republican Party v. Wash. Grange, No. 11-35125, slip op. at 480-83 (9th Cir. Jan. 19, 2011) (sustaining grant of summary judgment to defendants in First Amendment challenge to "top two" primary with party-preference ballot notations, and reasoning that, even though plaintiffs introduced statistical evidence of voter confusion, they had not created a triable issue of fact on whether a "well-informed electorate will interpret a candidate's party-preference designation to mean that the candidate is the party's chosen nominee or representative or that the party associates with or approves of the candidate" (quoting Wash. State Grange, 552 U.S. at 454)).

284. Tashjian v. Republican Party of Conn., 479 U.S. 208, 222-23 (1986).

285. Cal. Democratic Party v. Jones, 530 U.S. 567, 582 (2000).

286. Id.

287. 489 U.S. $214,227-28$. 
functions. ${ }^{288}$ Their importance is clear from the evidence, surveyed above, about the performance of nonpartisan elections and nonpartisan legislatures. Moreover, there is no reason to believe that a vertically integrated political party - one which fields candidates at multiple levels of government - will, if left to its own devices, perform these social functions well at each level. The Court's holdings in Tashiian, Eu, and Jones may be justifiable, ${ }^{289}$ but the reasoning the Court offered, if taken at face value, denies the very legitimacy of corrective state action in response to critical failures of the political market.

This cannot be right. But until the Court recognizes its error, "tailoring" reforms meant to influence the ideological content of the majorparty cues - such as forcing parties to allow primary-election participation by members who enroll for that level of government only-will face substantial constitutional roadblocks. This is further impetus for our party-substitutes strategies.

\section{How to Think About Burdens on Political Party Association}

Two postulates about the associational rights of political parties command broad agreement among legal scholars. First, political parties must enjoy some constitutional protections; they cannot be treated simply as playthings of the government. As Daniel Lowenstein put it, "[t]he idea of parties as 'public' is in tension ... with the need to assure that the party system maintains a basic autonomy from the state so that the parties may serve as vehicles for expressing the public's needs and sentiments." 290

Second, the autonomy or associational claims of major political parties must rest on something beyond a simple analogy to private expressive associations such as the Boy Scouts ${ }^{291}$ or the NAACP, ${ }^{292}$ the analogy on which the Supreme Court has relied. ${ }^{293}$ Parties do not have definite organizational boundaries, but instead consist of loose, often fractious, and sometimes shifting coalitions of interest groups, candidates, activists, and voters. ${ }^{294}$ Identifying who speaks for a private organization is easy

288. To be sure, the parties can and do perform other important functions. See generally Ethan J. Leib \& Christopher S. Elmendorf, Why Party Democrats Need Popular Democracy and Popular Democrats Need Parties, 100 CALIF. L. REv. 69, 83-91 (2012).

289. See, e.g., David Schleicher, "Politics As Markets" Reconsidered: Natural Monopolies, Competitive Democratic Philosophy and Primary Ballot Access in American Elections, 14 SUP. CT. ECON. REV. 163, 202-09 (2006) (defending Jones).

290. Daniel Hays Lowenstein, Associational Rights of Major Political Parties: A Skeptical Inquiry, 71 TEX. L. REV. 1741, 1750 (1993).

291. Boy Scouts of America v. Dale, 530 U.S. 640 (2000).

292. NAACP v. Ala. ex rel. Patterson, 357 U.S. 449 (1958).

293. See Richard H. Pildes, Foreword: The Constitutionalization of Democratic Politics, 118 HARV. L. REV. 28, 105-08 (2004) (noting and criticizing this reliance).

294. Lowenstein, supra note 292, at 1760, 1765; see also Elizabeth Garrett, Is the Party Over? Courts and the Political Process, 2002 SuP. CT. REV. 95, 109-10 (2002); Michael S. Kang, The Hydraulics and Politics of Party Regulation, 91 IOWA L. REV. 131, 142-46 (2005). 
enough; a charter of incorporation usually provides the answer. It is not so obvious, however, that the "official party charter," such as it is, should define who may speak for the party. Lowenstein pointed out that the "party-in-government"-consisting of elected officials who were nominated by the party membership (usually in primary elections) and subsequently voted into office - has at least as strong and probably a stronger claim to speaking for the party than little known officials of the nominal party organization.

Further, and more basically, the major parties don't exist primarily for expressive purposes..$^{295}$ The affiliates of a major party band together to elect candidates and to pressure those candidates, once elected, to heed the party-coalition's concerns. The Supreme Court recognized as much when it held, in Tashjian and Jones, that political parties have constitutionally protected interests not only in their private or "internal" domain, ${ }^{296}$ but also with respect to their "external" role of nominating ballot-qualified candidates for elective office. ${ }^{297}$

Finally, unlike most private associations, major parties under the American system of plurality-winner elections enjoy a natural duopoly. ${ }^{298}$ Entry by third parties is difficult because most citizens do not want to waste their votes on an impossible long shot, and because most talented candidates want a realistic shot at winning. The duopolistic nature of the major parties means that a party's decision to exclude a would-be joiner imposes much higher costs on the excluded person than analogous exclusionary acts by private expressive associations.

None of this is controversial. But despite sharing a common diagnosis of the problem of party associational rights, legal commentators have offered diametrically opposed solutions. Some would have the courts establish a near-absolute right for party organizations to structure candidate nomination processes as they wish; others would have the courts defer to the state-strongly in most cases, and almost categorically when the state action at issue was supported by elected officials from the plaintiff's political party.

295. See Bawn et al., supra note 135 (developing theory of why activists form parties); Nathaniel Persily, Toward a Functional Defense of Political Party Autonomy, 76 N.Y.U. L. REV. 750 (2001).

296. Over the years, many courts have tried to cabin party associational rights by distinguishing the parties "internal" and "external" activities, treating the former as constitutionally protected by analogy to private expressive associations and the latter as fully regulable state action. See, e.g., Eu v. S.F. Cnty. Democratic Cent. Comm., 489 U.S. 214, 231-33 (1989) (distinguishing state regulation of a party's "external responsibilities" from "direct regulation of a party's leaders" and "internal affairs"); Smith v. Allwright, 321 U.S. 649, 654 (1944) (holding that Democratic Party is state actor in nominating ballot-qualified candidates); Republican Party of Tex. v. Dietz, 940 S.W.2d 86, 92 (Tex. 1997) (holding that allocation of booths at party convention, and of advertising space in party publication, were "internal party affairs" as opposed to state action).

297. Cal. Democratic Party v. Jones, 530 U.S. 567, 575 (2000) ("In no area is the political association's right to exclude more important than in the process of selecting its nominee."); Tashjian v. Republican Party of Conn., 479 U.S. 208, 215-16 (1986) (treating the selection of candidates as the "basic function" of major parties).

298. Schleicher, supra note 289 , at $190-96$. 
On the pro-autonomy side, Nathaniel Persily argues that majorparty organizations must be allowed to structure their candidate nomination procedures largely as they wish, because "[p]arty autonomy ... acts as a critical mechanism for counteracting the majoritarian bias of America's plurality-based electoral systems." 299 Persily sees in the major parties a healthy tension between, on the one hand "the demands of competition" (pressure to nominate candidates who will appeal to the median voter), and the "demands ... of representation" (attending to groups in proportion to intensity of interest). ${ }^{300}$ Party organizations, rather than the state, should mediate these competing demands because this will "protect minorities' ability to band together into electoral coalitions with a real chance of gaining access to power." 301 Similarly, Michael Kang argues that absolute protection for "party autonomy" is the best way to ensure "a healthy balance of cooperation and competition" among players within the party coalition. ${ }^{302}$

Persily and Kang both assume that autonomous party organizations would create coherent, competitive political parties. But our analysis shows that this is not always the case: robust partisan competition, so important for competent voting and responsive government, is not an inevitable or natural state of affairs. ${ }^{303}$ Within a federal system, subnational governments are frequently dominated by one party for decades at a time. Indeed, a number of the Supreme Court's leading cases arose from one-party-dominated subnational jurisdictions - from the White Primary Cases, which dealt with racial minorities' access to primary ballots in Jim Crow Texas, ${ }^{304}$ to the recent decision in New York State Board of Elections $v$. Lopez Torres, ${ }^{305}$ which concerned the process for nominating major-party judicial candidates in perennially uncompetitive New York City.

The other pole in the party-rights debate was staked by Lowenstein, who prescribed judicial deference to the state in major-party autonomy cases. ${ }^{306}$ Most party rights claims are really just conflicts between different parts of the party coalition, Lowenstein observed, and no one has a better claim to resolve these disputes-to speak for the party as a whole - than the officials who have been nominated and elected to public office on the party label..$^{307}$

\footnotetext{
299. Persily, supra note 295 , at 811.

300. Id. at 819-20.

301. Id. at 820 .

302. Kang, supra note 294, at 175.

303. See supra Part II.B.

304. See generally SAMUEL ISSACHAROFF ET AL., THE LAW OF DEMOCRACY: LEGAL STRUCTURE OF THE POLITICAL PROCESS 208-25 (3d ed. 2007).

305. 552 U.S. 196 (2008).

306. Lowenstein, supra note 292 , at 1786 . For a related perspective, updating Lowenstein's argument, see Garrett, supra note 296, at 148-52.

307. Lowenstein, supra note 290 , at 1764-77.
} 
Whereas Persily and Kang place their faith in the party organization, Lowenstein puts his in the party-in-government. He makes a plausible argument that the party-in-government is more likely to represent the views of party-affiliated voters than are the titular leaders of the party organization. ${ }^{308}$ But it hardly follows that legislators elected on the party label will devote themselves to making the party into a competitive, coherent brand at the level of government in question. As a group, they may care more about holding onto their seats than building or maintaining a legislative majority. ${ }^{309}$ As individuals, their interests may lie in creating personal brands independent of their political parties, in running for office at a different level of government, or in becoming lobbyists.

Ultimately, we see little basis for privileging ex ante the judgments of the party organization or the party-in-government. If the ultimate goal is a system of competitive, coherent political parties, there is little choice but to examine, on a case-by-case basis, whether particular reforms would further or retard that objective. ${ }^{310}$ While this may be a difficult inquiry, it is far more likely to produce representation-enhancing rules than attempting to decide, once and for all, who speaks for the party.

As a doctrinal matter, courts could move in our direction by jettisoning the notion that there exists some tangible collective of persons ("the membership") that constitutes the party, and a corporeal leadership body that is presumptively entitled to govern the party and to determine what it stands for. The dominant parties in a two-party system should instead be understood as, in effect, publicly chartered corporations with a constitutionally conferred public function: to integrate voters and interest groups into coherent, competitive coalitions with respect to the government at issue, thereby enabling low-information voters to obtain representation and to hold the government accountable..$^{311}$

Anyone who wishes to associate in any manner with one of these umbrella coalitions should be permitted to bring an "associational rights" claim against state action that hinders the desired association, ${ }^{312}$ and no

308. After all, does anyone know for whom he voted the last time he cast a ballot for party selectman?

309. For each party caucus, redistricting presents a tradeoff between expanding the number of seats the party has a chance of winning (by redistributing reliable party voters from the caucus members' districts to other, potentially winnable districts), and protecting the security of the existing members of the caucus (who are more likely to lose a general election challenge if their core supporters are assigned to other districts).

310. For a related suggestion, see Samuel Issacharoff, Private Parties with Public Purposes: Political Parties, Associational Freedoms, and Partisan Competition, 101 COLUM. L. REV. 274 (2001).

311. We shall bracket for the time being whether there are other party functions that the party rights jurisprudence should protect.

312. Justice O'Connor's concurring opinion in Clingman v. Beaver, 544 U.S. 581 (2005) steps tentatively in this direction. See id. at 600-02 ("I question whether judicial inquiry into the genuineness, intensity, or duration of a given voter's association with a given party is a fruitful way to approach constitutional challenges to [primary regulations]"). 
party-affiliated actors should have a constitutionally protected right to accept or reject the proposed association. Rather, the presumptive permissibility of the challenged barrier to association - the "severity" of the "burden," as a matter of law-should depend entirely on whether the regulation tends to enhance or to retard the parties' performance of their designated public function. If it retards performance, it burdens associational rights within the meaning of the First Amendment; if it does not, there is no constitutionally cognizable harm.

A caveat: it is not our position that the First Amendment necessarily should be read in this way. That ultimate judgment requires a weighing of various interpretive and historical considerations we omit from our pragmatic analysis. Our point is simply that if one is willing to think about party rights in expressly functional terms, there is little basis for treating either the party organization or the party-in-government as presumptively entitled to control the candidate-nomination process.

\section{CONCLUSION: ELECTION LAW IN LIGHT OF VOTER IGNORANCE}

As a legal-academic field of study, election law has been centrally concerned with questions about the exclusion of disadvantaged voters, and the use of law to tilt the political field in favor of incumbents or the then-dominant party. These are important issues, but they exist on the abusive edge of the electoral arena. What we hope this paper shows is that there are very important election law questions that affect all voters in all elections, on the mainland of everyday politics and not just on its problematic shore.

Questions about voter competence are not about a distant "they," but rather are about "we," because, as E.E. Schattschneider noted over fifty years ago, in a complicated modern state "[t]here is no escape from the problem of ignorance, because nobody knows enough to run the government." ${ }^{1313}$ The central function of election law is to help citizens aggregate what little information they have into collectively sensible judgments about whether the people running the government should continue at the helm. The question of how well it performs this task should animate election law scholarship going forward. The quality of our democracy depends on it.

313. E.E. Schattschneider, The Semisovereign People: A Realist's View of DEMOCRACY IN AMERICA 136 (1960). 
